\title{
Copperas as Iron-Based Coagulant for Water and Wastewater Treatment: A Review
}

\author{
Nurul Aqilah Mohamad 1,2, Sofiah Hamzah 1,2,* (D), Mohammad Hakim Che Harun 1,2 (D), \\ Asmadi Ali 1,2 (D), Nazaitulshila Rasit 1,2 (D), Mohamad Awang 1,2, \\ Wan Rafizah Wan Abdul Rahman 1,2 (D), Alyza Azzura Abd. Rahman Azmi 1,3 (D), \\ Mohd Salleh Amri Zahid ${ }^{4}$, Ahmad Ariff Fahmi Mustofa ${ }^{4}$, Sa'adah Ahmed Latfi ${ }^{4}$, \\ Suhaimi Mohd Aripin ${ }^{4}$, Rozano Saad ${ }^{4}$
}

1 Environmental Sustainable Material Research Interest Group, Faculty of Ocean Engineering, Technology and Informatics, Universiti Malaysia Terengganu, 21030 Kuala Nerus, Terengganu Malaysia

2 Faculty of Ocean Engineering, Technology and Informatics, Universiti Malaysia Terengganu, 21030 Kuala Nerus, Terengganu Malaysia

3 Faculty of Science and Marine Environment, Universiti Malaysia Terengganu, 21030 Kuala Nerus, Terengganu, Malaysia.

4 Venator Asia Sdn. Bhd, Teluk Kalung, 24007 Kemaman, Terengganu

* Correspondence: sofiah@umt.edu.my (S.H.);

Scopus Author ID 54954085300

Received: 5.04.2021; Revised: 25.05.2021; Accepted: 28.05.2021; Published: 13.08.2021

\begin{abstract}
Ferrous sulfate, known as copperas, is generated from the titanium dioxide manufacturing industries. This by-product has been used in cement processing, agriculture, animal feed sector, printing industries, and water treatment. The coagulation/flocculation process is one of the treatment processes that can be used in this type of chemical coagulant in treating the water or wastewater sample. Considering the coagulation/flocculation process factor, copperas may be a coagulant that gives high removal efficiency. The main objective of the review is to identify the performance of copperas or a combination of copperas with other treatment or chemicals to unlocking its potential in the coagulation/flocculation process.
\end{abstract}

Keywords: Coagulation; Copperas; Ferrous sulfate; Wastewater treatment.

(C) 2021 by the authors. This article is an open-access article distributed under the terms and conditions of the Creative Commons Attribution (CC BY) license (https://creativecommons.org/licenses/by/4.0/).

\section{Introduction}

Copperas is a by-product of titanium production [1]. Titanium dioxide $\left(\mathrm{TiO}_{2}\right)$ is a pure white powder made from a simple inorganic compound [2]. It is a silvery-white material with low density, high strength, good corrosion resistance, very low thermal and electrical conductivity, and paramagnetic [3]. The application of $\mathrm{TiO}_{2}$ is very wide, including in coatings, plastics, paint, papers, printing inks, pharmaceuticals [4-8], cosmetic industry, textiles, food industry, and titanium dioxide nanomaterial $[2,3,9]$.

The overall $\mathrm{TiO}_{2}$ 's production is to convert an impure titanium mineral concentrates into pure white $\mathrm{TiO}_{2}$ pigment. There are two distinct processes in the $\mathrm{TiO}_{2}$ manufacturing process: the sulfate and chloride processes [2]. Both processes begin with the impure mineral feedstock of $\mathrm{TiO}_{2}$. But the production of copperas was mainly formed from the sulfate process.

The sulphate process, use several feedstocks namely, ilmenite $\left(40 \%-60 \% \mathrm{TiO}_{2}\right)$, titanium slag $\left(72 \%-85 \% \mathrm{TiO}_{2}\right)$ or a mixture of those materials, which were digested with concentrated sulphuric acid $[3,10]$. This process was to obtain the pigment of titanium dioxide. The general digestion reaction equation (raw material digestion) is as follow [2,10,11]: 


$$
\begin{aligned}
& \mathrm{FeTiO}_{3}+2 \mathrm{H}_{2} \mathrm{SO}_{4} \rightarrow \mathrm{TiOSO}_{4}+\mathrm{FeSO}_{4}+2 \mathrm{H}_{2} \mathrm{O} \text { (Digestion) } \\
& \mathrm{Fe}_{2}\left(\mathrm{SO}_{4}\right)_{3}+\mathrm{Fe}^{\circ} \rightarrow 3 \mathrm{FeSO}_{4} \text { (ferric reduction) } \\
& \mathrm{FeSO}_{4}+7 \mathrm{H} 2 \mathrm{O} \rightarrow \mathrm{FeSO}_{4} \cdot 7 \mathrm{H}_{2} \mathrm{O} \text { (crystallisation) } \\
& \mathrm{TiOSO}_{4}+\mathrm{H}_{2} \mathrm{O} \rightarrow \mathrm{TiO}_{2} \mathrm{n} . \mathrm{H}_{2} \mathrm{O}+\mathrm{H}_{2} \mathrm{SO}_{4} \text { (Hydrolysis) } \\
& \mathrm{TiO}_{2} \mathrm{n} . \mathrm{H}_{2} \mathrm{O} \rightarrow \mathrm{TiO}_{2}=\mathrm{n} . \mathrm{H}_{2} \mathrm{O} \text { (Calcination) }
\end{aligned}
$$

The sulfate process is the main process used in producing $\mathrm{TiO}_{2}$ compared to chloride due to its simpler technology and lower grade and cheaper raw materials to produce a form of pigment [3]. The overview of the sulfate process was as shown in Figure 1.

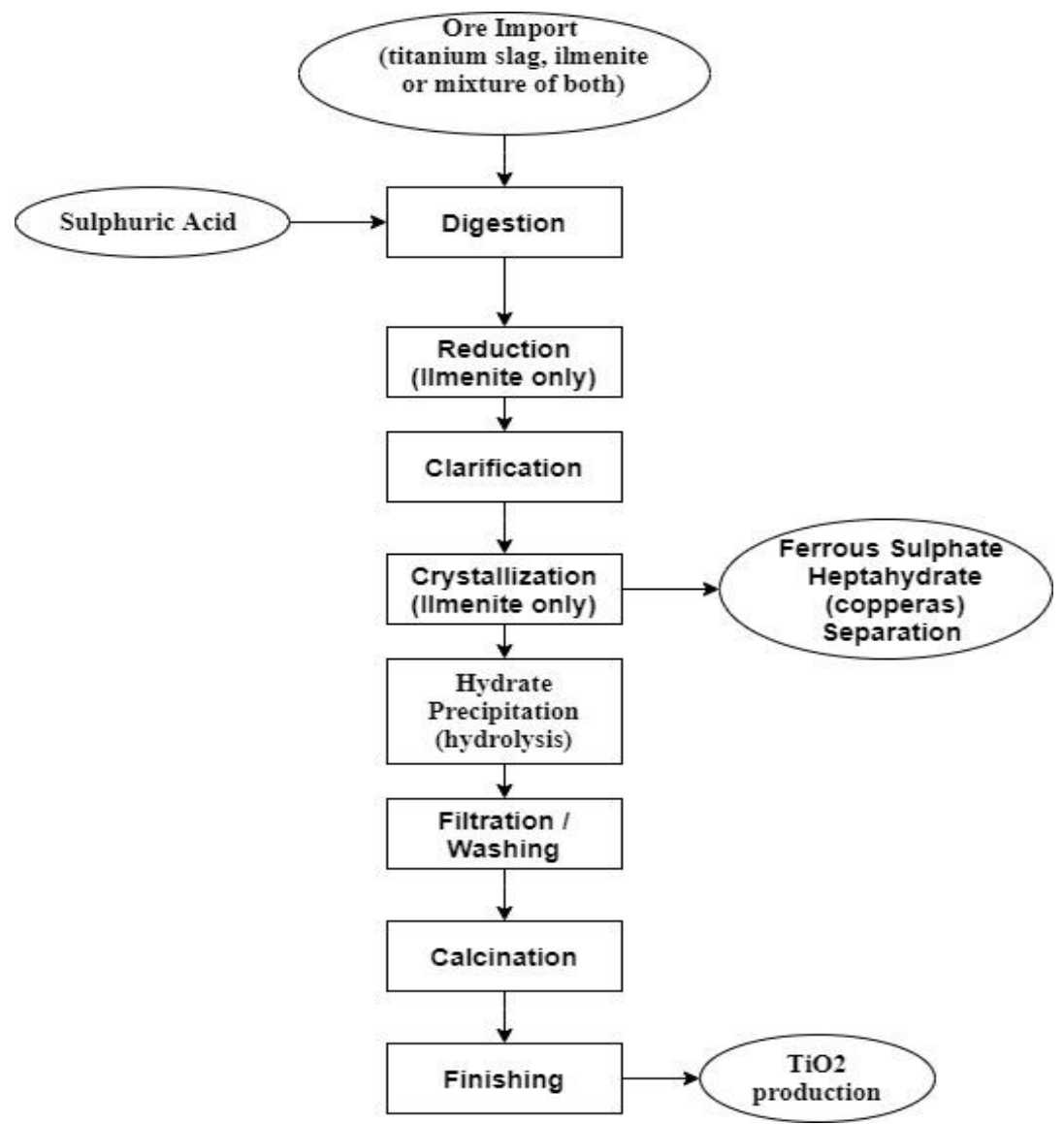

Figure 1. Sulfate process of $\mathrm{TiO}_{2}$ production.

As shown in Figure 1, $\mathrm{FeSO}_{4} .7 \mathrm{H}_{2} \mathrm{O}$ is formed from the crystallization process where the hydrated $\mathrm{TiO}_{2}$ comes from the separation stage and then was injected into crystallizers [12]. This $\mathrm{FeSO}_{4} .7 \mathrm{H}_{2} \mathrm{O}$ is the first by-product formed from the $\mathrm{TiO}_{2}$ process that also known as copperas. It is also known as ferrous sulfate, green copper, green vitriol, iron vitriol or melanterite, sugar sulfate, iron sugar, ferrous sulfur, pyrosulphate of iron, and iron (II) sulfate [3,13,14]. About 3.4-4.2 tonnes of copperas were produced per tonne of titanium dioxide extracted in the manufacturing of $\mathrm{TiO}_{2}[15,16]$. The huge production of this by-product has a risk in the environment as it contains a high level of leachable ions $\left(\mathrm{Fe}^{2+}\right.$ and $\left.\mathrm{SO}_{4}{ }^{2+}\right)$ [15].

Many studies have been conducted on the use of copperas. These will reduce this byproduct produce from the $\mathrm{TiO}_{2}$ production and will reduce the risks to environmental pollution. Previous findings showed that it was possible to use copperas as magnetic nanoparticles (Fe3O4 NPs) [15,17], culturing Chlorella Vulgaris for energy production [18], amination of glyoxylic acid [19], increasing the iron of ammonium iron blue [20], production of iron oxide pigments [12], preparation of electroactive nanofluid [21] and processes of bamboo charring 
impregnated with copperas [22]. The copperas has also been used in cement processing as a reduction agent of chromium VI [23,24], in agriculture in allowing the plant's growth and preventing snails, in the animal feed sector and manufacturing of ink and toner for printing industries [25].

Another application of copperas is for water purification and eliminating phosphate for wastewater treatment plants [3]. Copperas have also been used to apply electroplating treatment in combination with hydrogen peroxide, giving $60 \%, 60 \%$, and $50 \%$ of $\mathrm{Cr}, \mathrm{Cu}$, and $\mathrm{Ni}$ removal, respectively [26]. The application of an anoxic/oxic reactor may reduce the total phosphorus below $1 \mathrm{mg} / \mathrm{L}$ and 78 to $85 \%$ of nitrogen removal efficiency. Using copperas for industrial wastewater reduces 410 to $283 \mathrm{mg} / \mathrm{L}$ of Chemical Oxygen Demand (COD), about $31 \%$ removal [27]. It was highly capable of adsorbing oil fragments and suspended solid (SS) from wastewater from the refinery and reducing the economic cost [28]. Mcnulty has stated the application of copperas in various industries that copperas is a solid form for various uses, including water treatment, cultivation, and cement use [2].

This review briefly summarizes the properties and characteristics of copperas and their utilization in the coagulation/flocculation process, including the process condition for the treatment. It also includes the performance of copperas alone, an integration of copperas with other coagulant aid, and the coupling of coagulation/flocculation with hydrogen peroxide in removing the pollutant of various types of water or wastewater.

\section{Properties and characteristics of copperas}

Copperas is an inorganic coagulant commercially available and a cheaper coagulant as compared to other coagulants such as synthetic polyelectrolytes. It is perhaps the cheapest of all salts that can be used for coagulation, stated by Matilainen et al. and Sahu \& Chaudhari [29,30]. A bottle of $\mathrm{FeSO}_{4}$ is equal to RM65.00 [31]. Copperas can be used as a coagulant in removing the pollutant. It is a positively charged that attracts the negatively charged counter ions that are present in the colloidal suspensions to form small flocks.

Copperas is turquoise or blue-green, odorless, and crystal solid. Its melting point is 68 ${ }^{\circ} \mathrm{C}$ and decomposes at $>300^{\circ} \mathrm{C}$. The salts are soluble in water. They tend to lose or gain water molecules depending on the medium when reacted. In water, ferrous sulfate salts are hydrolyzed, forming the aqueous complex $\left[\mathrm{Fe}\left(\mathrm{H}_{2} \mathrm{O}\right)_{6}\right]^{+2}$. While, if they contact the air, these salts will lose water molecules. The chemical composition of copperas was given in Table 1.

Table 1. Chemical composition of copperas.

\begin{tabular}{c|c|c} 
Constituent & $\begin{array}{c}\text { Wt. \% } \\
{[\mathbf{3 2}]}\end{array}$ & $\begin{array}{c}\text { Wt. , \% } \\
{[\mathbf{3 3}]}\end{array}$ \\
\hline $\mathrm{FeO}$ & 27.82 & $39 \pm 3$ \\
\hline $\mathrm{SO}_{3}$ & 30.72 & $22 \pm 2$ \\
\hline $\mathrm{MgO}$ & 1.73 & $0.25 \pm 0.03$ \\
\hline $\mathrm{MnO}$ & 0.14 & $0.35 \pm 0.04$ \\
\hline $\mathrm{TiO}_{2}$ & 0.18 & $0.18 \pm 0.02$ \\
\hline $\mathrm{Al}_{2} \mathrm{O}_{3}$ & 0.014 & $<0.01$ \\
\hline $\mathrm{SiO}_{2}$ & $\leq 0.005$ & $<0.01$ \\
\hline $\mathrm{CaO}$ & - & $<0.01$ \\
\hline LOI (loss on ignition) on $1000^{\circ} \mathrm{C}$ & 62.12 & -
\end{tabular}

From Table 1 it is shown that the copperas contains a high proportion of $\mathrm{FeO}$ and $\mathrm{SO}_{3}$ from both studies conducted. Other constituents showed a low level of $\mathrm{Al}_{2} \mathrm{O}_{3}, \mathrm{SiO}_{2}, \mathrm{CaO}$, and $\mathrm{TiO}_{2}$. A low amount of these impurities is due after the titanium dioxide precipitation during the crystallization of the stream [33]. 
Another study by Aziz \& Wan Kamar reported that both analytical grade ferrous sulfate and copperas by-product showed that both coagulants have similar characteristics even though they were produced differently [34]. The $\mathrm{pH}$ values were 3.0 and 2.95, and its zeta potential were $-7.3 \mathrm{mV}$ and $-7.5 \mathrm{mV}$ for both analytical grade ferrous sulfate and copperas by-product. The characterization of copperas by-products was further investigated by Gázquez et al., $[3,33]$. The method used in determining its characterization was X-ray diffraction for its mineralogical. It stated that the copperas co-products indicate that the compounds are extremely unstable it was found that a fraction of reozenite and melanterite mineralogical form has been examined [33].

\section{Application of copperas as a coagulant in wastewater treatment}

Wastewater generation typically involves very fine suspended solids, dissolved solids, inorganic and organic particles, metals, and other impurities from various kinds of industries. The suspended particles may differ in source, charge, particle size, shape, and density [35]. Discharging the wastewater into waterways and drains leads the water sources to not compete with pollution load even though the water can dilute the contaminants in the water bodies [36]. Increasing the amount of wastewater discharged poses human health and environmental issues, including aquatic life. The treatment includes membrane technology [37-39], filtration [40,41], flotation [42,43], adsorption [44-46], coagulation/flocculation [47-50], capacitive deionization [51,52], ion exchange [53,54] and oxidation [55-57]. Details in each treatment can be seen in Ouyang et al. [58].

\subsection{Coagulation-flocculation process.}

The coagulation-flocculation process is one of the wide purification methods that have been used for urban and industrial wastewater [59]. It is the process that has been successfully used in different types of industries. Coagulation was used as a pre-treatment to remove a significant amount of colloidal and particulate organics matter in residual waters. It is an easy process due to its operation, relatively simple design, and only consumes low energy [60]. Due to its ability in treating water, coagulation-flocculation can also be used as pre-treatment, posttreatment, or even as the main treatment of wastewater [61].

In general, coagulation-flocculation in water or wastewater treatment involves adding chemicals to change the physical condition of dissolved and suspended solids to facilitate their removal through the coming sedimentation process [62]. Coagulation consists of physical and chemical reactions between the water alkalinity and the water coagulant, contributing to the creation of insoluble flocs [63]. The process aggregates fine particles and colloids into larger particles to reduce turbidity, natural organic matter, and other soluble organic and inorganic pollutants in wastewater [64,65]. It consists of two stages: rapid mixing of coagulant into water or wastewater to be treated by a strong agitation followed by the flocculation by gentle agitation for the accumulation of small particles into flocs. The flocs will be allowed to settle and then removed as sludge, while the supernatant, which is the treated water or wastewater, will transfer into subsequent treatment or the watercourse for discharge [64]. Figure 3 illustrates the mechanism of coagulation-flocculation for water or wastewater treatment. 


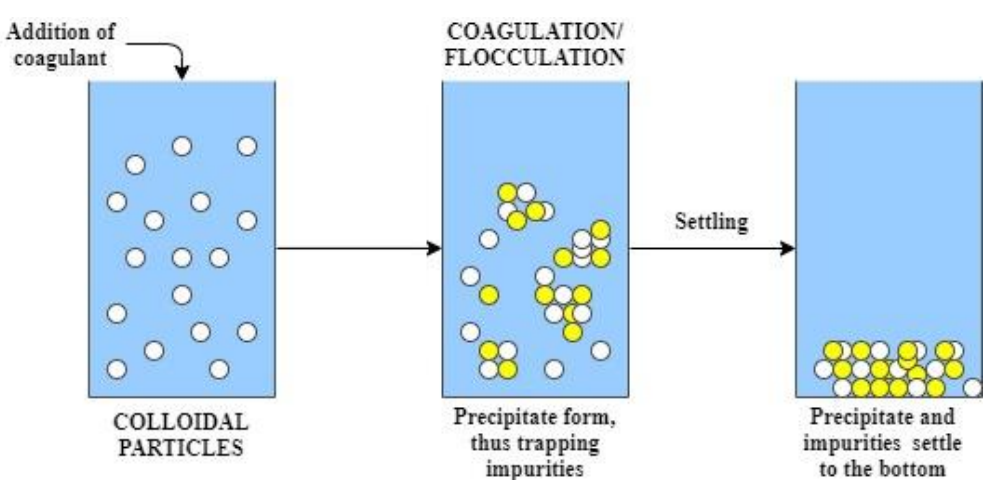

Figure 3. Coagulation-flocculation mechanisms.

\subsection{Reaction of copperas in the coagulation treatment process.}

The ferrous sulfate had been used in water and wastewater treatment. It also has been used for the removal of nitrogen [66], chemical phosphorus removal [66-68], and as a coagulant in the plant for municipal wastewater treatment [16]. It can also be used to avoid membrane fouling in membrane technologies in treating domestic wastewater [68] and precipitation in treating municipal wastewater for phosphorus removal in a low dose of ferrous sulfate [69]. The copperas will be dissolved in water before it was used for those treatments. When this occurs, it will dissociate as a reaction in Equation 6 below:

$$
\mathrm{FeSO}_{4} \rightarrow \mathrm{Fe}^{2+}+\mathrm{SO}_{4}^{2-}
$$

Normally, lime is added to raw wastewater either before or after treatment before $\mathrm{pH}$ adjustment. The chemical reactions in ferrous coagulation treatment are shown in Equation 7 $[14,63,70-72]$.

$$
\mathrm{FeSO}_{4} .7 \mathrm{H}_{2} \mathrm{O}+\mathrm{Ca}(\mathrm{OH})_{2} \rightarrow \mathrm{Fe}(\mathrm{OH})_{2}+\mathrm{CaSO}_{4}+7 \mathrm{H}_{2} \mathrm{O}
$$

The reaction that occurs when the copperas is added to lime earlier was as below [71].

$$
\begin{aligned}
& \mathrm{FeSO}_{4} .7 \mathrm{H}_{2} \mathrm{O}+\mathrm{Ca}\left(\mathrm{HCO}_{3}\right)_{2} \rightarrow \mathrm{Fe}\left(\mathrm{HCO}_{3}\right)_{2}+\mathrm{CaCO}_{3}+7 \mathrm{H}_{2} \mathrm{O} \\
& \mathrm{Fe}\left(\mathrm{HCO}_{3}\right)_{2}+2 \mathrm{Ca}(\mathrm{OH})_{2} \rightarrow \mathrm{Fe}(\mathrm{OH})_{2}+2 \mathrm{CaCO}_{3}+2 \mathrm{H}_{2} \mathrm{O}
\end{aligned}
$$

$\mathrm{Fe}(\mathrm{OH})_{2}$ will gets oxidized forming $\mathrm{Fe}(\mathrm{OH})_{3}$ in the presence of oxygen [42,50,51]. The oxidation reaction is as in Equation 10.

$$
4 \mathrm{Fe}(\mathrm{OH})_{2}+\mathrm{O}_{2}+2 \mathrm{H}_{2} \mathrm{O} \rightarrow 4 \mathrm{Fe}(\mathrm{OH})_{3}
$$

In the coagulation process, the precipitate form (ferric hydroxide) is the most insoluble precipitate compared to the ferrous form. The formation will form the floc and thus help the sedimentation process [71]. But this reaction cannot be avoided as oxygen is always available in the water.

\subsection{Process condition of coagulation treatment using copperas.}

As discussed earlier, coagulation and flocculation are used to separate suspended solids from water or industrial wastewater for acceptable value before being discharged to the 
watercourse, which includes both physical and chemical processes carried out in sequence, as shown in Figure 4. Chemicals will be added to the wastewater to encourage the aggregation of the suspended solid into large particles to settle or be removed significantly [73]. Coagulation is based on neutralizing electrostatic repulsion by incorporating particles with the opposite charge of particles [27]. With proper coagulation, an acceptable discharge limit can be achieved for the effluent, not harming the environment.

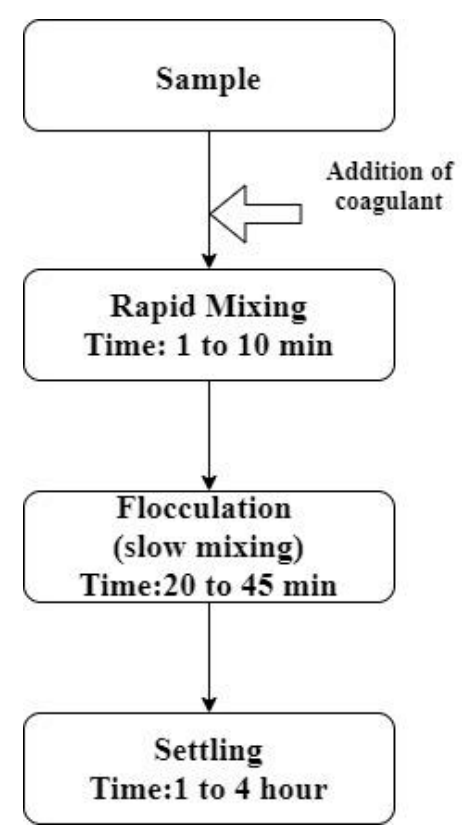

Figure 4. Coagulation mechanism phases.

The effectiveness of the coagulation-flocculation process depends on many variables that include the type of coagulant used, dosage, $\mathrm{pH}$, its feed concentration, type, and dosage of chemical additive $[30,63]$.

\subsubsection{Influence on type of coagulant.}

One of the most critical choices for water or wastewater treatment is the option of coagulant to be used. Different coagulant reacts differently for different water quality parameters [30]. The most commonly used metal coagulants for the coagulation/flocculation process are aluminum and iron-based coagulants [64]. Those coagulants are simple, easy to handle, cheap, and have a good wastewater removal efficiency [74,75]. To neutralize the charges on the particles that then will agglomerate to form floc and promote the removal of colloidal particles, as the coagulant was added to [76]. Nandy et al., stated that the use of aluminium and iron salts as coagulants even at low concentrations has resulted in the creation of visible flocs, which could be caused by destabilization and further neutralization of the charged particles [77].

The aluminum coagulant is consists of alum, aluminum chloride, and sodium aluminate, while iron coagulant consists of ferrous sulfate, ferric chloride, and ferric sulfate [30]. In the last two decades, pre-polymerized coagulants have been widely used consists of poly aluminum chloride (PAC), poly aluminum sulfate (PAS), and poly aluminum chlorosulfate (PACS) [78]. These coagulants can operate effectively across various $\mathrm{pH}$, temperature, and colloid concentrations compared to common coagulants. It can remove the hazardous 
organic materials from wastewater, rendering it ideal for secondary treatment such as wet air oxidation or biological treatment [79].

\subsubsection{Influence of coagulant dosage.}

The coagulant dosage was one of the important parameters in the coagulation/flocculation process. A study by Sahu \& Chaudhari stated that the coagulant concentration should be proportional to the concentration of the organic matter present in the solution, either water or wastewater sample [30]. It needed to be applied appropriately to destabilize the organic matter before the water quality parameters can be eliminated [30].

Equation 9 below showed the dissolution of ferrous sulfate in the coagulation process [80]. $\mathrm{FeSO}_{4}$ reacts in water forming insoluble metal hydroxide, and adsorbs it on the surface of colloidal particles. The addition of $\mathrm{FeSO}_{4}$ will remove the organic matter by reducing its molecular weight $[81,82]$.

$$
\mathrm{FeSO}_{4}+2 \mathrm{HCO}_{3}^{-} \rightarrow \mathrm{Fe}(\mathrm{OH})_{2}+\mathrm{SO}_{4}^{-2}+2 \mathrm{CO}_{2}
$$

Normally, the removal increase as the coagulant dosage increases as the ferrous hydroxide precipitates increase. This might also increase the adsorptive surface, thus increasing the removal of a colloidal particle [83]. Increasing coagulant dosage will increase its performance in terms of removal efficiency until it reaches its optimum dosage [84]. This is due to the destabilization of the colloidal particle in which the concentration of $\mathrm{Fe}^{2+}$ increases as the coagulant dosage increase [85]. The decreasing of the removal would happen when it reaches its optimum value [34]. A study stated that when the dosage used is higher than the optimum value and resulted in lower removal efficiency, it could be due to the destabilization of the colloidal particle [81] and the reversion of the surface charges of the particles [83]. Duan $\&$ Gregory also stated that excess dosage can reverse the charge and colloid restabilization [86].

A study conducted by Hossain et al. reported on the higher removal efficiency of COD, Biochemical Oxygen Demand (BOD), and total suspended solids (TSS), which at 2g/L and $4 \mathrm{~g} / \mathrm{L}$, respectively, for industrial wastewater [47]. Other studies have been conducted by Ismail et al. on municipal wastewater showed that its optimum dosage was at $0.080 \mathrm{~g} / \mathrm{L}$ [84]. A study conducted by Al-Gheethi et al. showed that the highest removal of turbidity and TSS were at a high dosage $(0.12 \mathrm{~g} / \mathrm{L})$ and COD at a lower dosage $(0.030 \mathrm{mg} / \mathrm{L})$ of FeSO4 [87]. The dosage of ferrous sulfate used for pollutant removal may depend on the initial concentration of the selected quality of water or wastewater. Reducing the initial concentration will induce changes in the required coagulant dosage for treatment [88].

\subsubsection{Influence of initial $\mathrm{pH}$.}

$\mathrm{pH}$ plays an important role in the coagulation/flocculation process. It will affect the removal of the pollutant in the water and wastewater. It will also change the coagulant's surface charges and the stabilization of the suspension [34,83]. The $\mathrm{pH}$ will be adjusted so the coagulation/flocculation process will be more effective in removing the pollutant. The $\mathrm{pH}$ was also influenced by the coagulant types used, coagulant concentration, and the composition of the sample used $[81,83]$.

The addition of ferrous sulfate in the solution will decrease the $\mathrm{pH}$ value as the ferrous will precipitate into both hydroxide forms and hydrogen ions [89]. The iron precipitates will 
include the production of $\mathrm{Fe}^{3+}, \mathrm{FeOH}^{2+}, \mathrm{Fe}(\mathrm{OH})_{2}{ }^{+}$and $\mathrm{Fe}(\mathrm{OH})_{3}$ using iron-based coagulants [90]. Precipitation iron (III) hydroxide as shown in Equation below [48]:

$$
\begin{aligned}
& \mathrm{FeSO}_{4} .7 \mathrm{H}_{2} \mathrm{O} \rightarrow \mathrm{Fe}^{2+}+\mathrm{SO}_{4}{ }^{2-}+7 \mathrm{H}_{2} \mathrm{O} \\
& \mathrm{Fe}^{2+}+2 \mathrm{H}_{2} \mathrm{O} \rightarrow \mathrm{Fe}(\mathrm{OH})_{2} \downarrow+\mathrm{H}_{2} \\
& 4 \mathrm{Fe}(\mathrm{OH})_{2}+2 \mathrm{H}_{2} \mathrm{O}+\mathrm{O}_{2} \rightarrow 4 \mathrm{Fe}(\mathrm{OH})_{3}
\end{aligned}
$$

Ferrous sulfate was efficient over a wide $\mathrm{pH}$ range from 3 to 13 [77]. Irfan et al. state that the optimum $\mathrm{pH}$ value for COD and TSS at acidic conditions may be attributed to paper mill effluents' heavy precipitation [91]. For the palm oil mill effluent sample, it resulted in an increased removal at the range of $\mathrm{pH} 2$ to 5 with 70\%, 78\%, and 84\% of COD, BOD, and TSS, respectively, and increasing the $\mathrm{pH}$ afterward resulted in decreasing its removal [47]. Same findings on the $\mathrm{pH}$, which at $\mathrm{pH} 5$ the COD reduce about $12 \%$ and $42 \%$ TSS removal at $\mathrm{pH} 4$ on the coagulation using paper mill effluent [91]. A study conducted on leachate samples showed that the removal was higher at a low or higher $\mathrm{pH}$ value [81]. A study stated that the reduction of COD and color is due to the creation of positive charges for iron salts species, which normally happens between $\mathrm{pH} 5$ and 8 [92].

At a high $\mathrm{pH}$ range ( $\mathrm{pH} 7-10)$, copperas was effective in treating dairy wastewater [93]. Another study stated that at a higher $\mathrm{pH}$ value at $\mathrm{pH} 8$ showed a higher removal of COD, about $65.3 \%$ using ferrous sulfate [85]. Ferrous sulfate was also successful at $\mathrm{pH} 9$, producing ferrous hydroxide in the alkaline range for arsenate removal from tap water [88]. Khajabu \& Gupta stated that the copperas works efficiently at $\mathrm{pH} 8.5$ and above [71]. A wide range of $\mathrm{pH}$ in the treatment of petroleum refinery wastewater was observed. It resulted in the increasing removal efficiency for COD and color as the $\mathrm{pH}$ increase [83]. The reduction at $\mathrm{pH}>8$ was due to the formation of positively charged $\mathrm{Fe} 2+$ and $\mathrm{Fe}(\mathrm{OH})+$ and neutral $\mathrm{Fe}(\mathrm{OH}) 2$ hydrolysis species triggered stronger colloidal removal at $\mathrm{pH}>8$ [93].

From all findings, it was found that copperas has a good performance at a wide $\mathrm{pH}$ range depending on the sample conditions. This indicates that coagulation's ideal $\mathrm{pH}$ not only relies on the form of coagulants but also on the quality of the sample [94].

\subsubsection{Influence of mixing speed and its time.}

The effect of mixing speed and the mixing time of the coagulant with the selected sample was also important in identifying the performance of the coagulation/flocculation process. It is to ensure that the coagulant is mixed to treat the solution at the preferable timing. The efficiencies of pollutant removal may reduce when the mixing speed was very fast and the mixing time was longer, but the flocs would not have been produced because of the insufficient interaction of the coagulants with the effluent when the mixing period was short [95]. A study by Sahu \& Chaudhari states that high mixing speed can ensure rapid hydrolysis of the coagulant and the interaction between the supernatant and the suspended solids [30]. It also may slow down the creation of large flocs that are inactive in destabilizing the dispersion and eliminating the pollutant [30]. Another study on the coagulation/flocculation process on palm oil mill effluent treatment states that the flocs produce will break up if too high a mixing speed has been introduced to the solution and poor performance [96].

For mixing time, ferrous showed a great removal at a longer time (210 min) with a final turbidity value of $3.31 \mathrm{NTU}$, and increasing over $210 \mathrm{~min}$, the final turbidity value started to increase [97]. With a shorter mixing time, the poor removal of the pollutant was due to the low 
collisions between coagulants. It suspended particles that resulted in lower floc formation for sedimentation [48].

\subsubsection{Influence of sedimentation time.}

The effect of settling time also a crucial factor was affecting the coagulation/flocculation process. This parameter is influenced by gravity, in which the heavier flocs will settle faster than the particles that are scattered [96]. Ngteni et al. stated that increasing the sedimentation time will improve the coagulation efficiency [48]. Same as coagulant dosage, increasing the sedimentation time over their optimum time will reduce performance removal.

\subsubsection{Influence of different temperatures.}

A study by Sahu \& Chaudhari states that the temperature influences the solubility of the precipitates of metal hydroxide and the rate of formation of the products from metal hydrolysis as it will influence the coagulation/flocculation process [30]. The effect on temperature could increase the kinetic energy of iron (II) particles, encouraging further collisions with the organic particles that negatively charged ions, thus improving the efficiency of the coagulation process [47]. Hydrolyzing metal coagulants were observed to perform less well at low temperatures [86]. A study conducted on an effluent sample from a palm oil mill reported a high removal of pollutants at a range of $60-70^{\circ} \mathrm{C}$ [47]. With the growing temperature above $70^{\circ} \mathrm{C}$, the adsorption efficiency decrease may be attributed to weakening the beneficial intermolecular force between coagulant particles and organic particles in water or wastewater samples [48]. Even though it has resulted in high removal efficiency, but the implementations might be expensive if the temperature is higher or lower than its original temperature.

\subsection{Evaluation of copperas as a chemical coagulant for wastewater treatment.}

Domestic or industrial effluent such as agricultural wastewater contains mostly organic substances such as free and emulsified oil/fat, TSS, organic colloids, sludge, and inorganic dissolved substances. Different effluents have different characteristics of water quality. It depends on the type of wastewater itself. All of them can give environmental impact if it is released into the watercourse without adequate treatment. The potential benefit of using copperas as a coagulant is that the sludge produced could be treated as a non-hazardous substance and used as an organic fertilizer [48]. Verma, Dash, et al. stated that it is also possible to consider ferrous sulfate as a stronger coagulant than other metallic salts that are hydrolyzed [98].

The findings on the copperas performance were tabulated in Table 3. It showed the performance of copperas in treating various types of effluent by coagulation-flocculation. Copperas is a coagulant was widely used for the paint industry [99], municipal and industrial wastewater treatment. It was found that ferrous sulfate was the most successful removal of COD, BOD, and color. Fe (II) that removes color can be linked to Fe (III) [100].

Table 3. Performance of copperas for various industries by coagulation/flocculation process.

\begin{tabular}{|c|c|c|c|c|c|c|c|c|c|c|c|}
\hline \multirow{2}{*}{$\begin{array}{l}\text { Type of } \\
\text { wastewater }\end{array}$} & \multirow{2}{*}{$\begin{array}{l}\text { Optimum } \\
\text { condition }\end{array}$} & \multicolumn{9}{|c|}{ Percentage removal (\%) } & \multirow[t]{2}{*}{ Ref. } \\
\hline & & COD & BOD & DO & Colour & TSS & TDS & SS & Turbidity & $\left(\mathrm{PO}_{4}\right)^{3-}$ & \\
\hline $\begin{array}{l}\text { Car wash } \\
\text { wastewater }\end{array}$ & $\begin{array}{l}\text { Dosage: } 0.15 \\
\mathrm{~g} / \mathrm{L}\end{array}$ & 71 & - & - & - & - & - & - & 77 & 65 & {$[31]$} \\
\hline
\end{tabular}




\begin{tabular}{|c|c|c|c|c|c|c|c|c|c|c|c|}
\hline \multirow{2}{*}{$\begin{array}{l}\text { Type of } \\
\text { wastewater }\end{array}$} & \multirow{2}{*}{$\begin{array}{l}\text { Optimum } \\
\text { condition }\end{array}$} & \multicolumn{9}{|c|}{ Percentage removal $(\%)$} & \multirow[t]{2}{*}{ Ref. } \\
\hline & & COD & BOD & DO & Colour & TSS & TDS & SS & Turbidity & $\left(\mathrm{PO}_{4}\right)^{3-}$ & \\
\hline Cotton dyeing & $\begin{array}{ll}\begin{array}{l}\text { Dosage: } \\
\text { g/L }\end{array} & 0.2 \\
\end{array}$ & 78 & - & - & - & - & - & - & - & - & $\begin{array}{l}{[101} \\
]\end{array}$ \\
\hline $\begin{array}{l}\text { Cotton textile } \\
\text { wastewater }\end{array}$ & 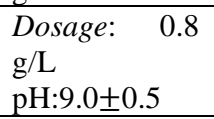 & 50 & - & - & $80-90$ & - & - & - & - & - & $\begin{array}{l}{[102} \\
]\end{array}$ \\
\hline \multirow[t]{4}{*}{$\begin{array}{l}\text { Dairy } \\
\text { wastewater }\end{array}$} & $\begin{array}{ll}\text { Dosage: } & 0.8 \\
\mathrm{~g} / \mathrm{L} & \\
\text { pH: } 8.0 & \\
\text { Mixing } & \text { time: } \\
30 \mathrm{~min} & \\
\end{array}$ & 66.5 & - & - & - & - & - & - & - & - & {$[85]$} \\
\hline & $\begin{array}{ll}\text { Dosage: } & 0.1 \\
\mathrm{~g} / \mathrm{L} & \\
\text { pH: } 5.0 & \\
\end{array}$ & 62 & - & - & - & - & - & - & 95 & - & $\begin{array}{l}{[103} \\
]\end{array}$ \\
\hline & $\begin{array}{ll}\begin{array}{l}\text { Dosage: } \\
\mathrm{g} / \mathrm{L}\end{array} & 0.2 \\
\end{array}$ & 60 & - & - & - & - & - & - & 65 & - & {$[82]$} \\
\hline & $\begin{array}{l}\text { Dosage: } \\
\mathrm{mL} / \mathrm{L} \\
\mathrm{pH}: 7.0\end{array}$ & 64 & 68 & - & - & 84 & 83 & - & 94 & - & {$[93]$} \\
\hline \multirow[t]{2}{*}{$\begin{array}{l}\text { Domestic } \\
\text { wastewater }\end{array}$} & $\begin{array}{ll}\text { Dosage: } & 0.2 \\
\text { g/L } & \\
\text { pH: } 9.0 & \\
\end{array}$ & - & - & - & 80 & - & - & - & - & - & \multirow[t]{2}{*}{ [34] } \\
\hline & $\begin{array}{ll}\text { Dosage: } & 0.15 \\
\mathrm{~g} / \mathrm{L} & \\
\text { pH: } 9.0 & \\
\end{array}$ & - & - & - & 73 & - & - & - & - & - & \\
\hline $\begin{array}{l}\text { Industrial } \\
\text { wastewater }\end{array}$ & $p H: 8.5-10$ & - & - & - & - & - & - & - & - & 80 & $\begin{array}{l}{[104} \\
]\end{array}$ \\
\hline \multirow[t]{2}{*}{$\begin{array}{l}\text { Laundry } \\
\text { wastewater }\end{array}$} & $\begin{array}{l}\text { Dosage: } \\
0.0025 \mathrm{~g} / \mathrm{L} \\
\text { pH: } 8.20\end{array}$ & - & - & - & - & - & - & - & - & 5.0 & [89] \\
\hline & $\begin{array}{l}\text { Dosage: } 0.03 \\
\mathrm{~g} / \mathrm{L}\end{array}$ & 54.81 & - & - & - & - & - & - & 59.02 & - & [87] \\
\hline \multirow[t]{2}{*}{ Leachate } & $\begin{array}{ll}\text { Dosage: } & 0.6 \\
\mathrm{~g} / \mathrm{L} & \\
\mathrm{pH}: 12.0 & \\
\end{array}$ & 14.9 & - & - & 63 & - & - & $\begin{array}{l}81 \\
.6\end{array}$ & - & - & [81] \\
\hline & $\begin{array}{ll}\text { Dosage: } & 1.5 \\
\mathrm{~g} / \mathrm{L} & \\
\text { pH: } 12.0 & \\
\end{array}$ & 70.66 & - & - & - & - & - & - & - & - & $\begin{array}{l}{[105} \\
]\end{array}$ \\
\hline $\begin{array}{l}\text { Municipal } \\
\text { wastewater }\end{array}$ & $\begin{array}{l}\text { Dosage: } 0.080 \\
\text { pH: } 6-6.5 \\
\text { Mixing speed: } \\
350 \mathrm{rpm} \\
\text { Mixing } \\
\text { time: } 60 \mathrm{sec} \\
\text { Temp.: } 30^{\circ} \mathrm{C} \\
\text { Sedimentation } \\
\text { time: } 30 \mathrm{~min}\end{array}$ & 56 & 48 & - & - & 74 & - & - & - & 69 & [84] \\
\hline $\begin{array}{l}\begin{array}{l}\text { Olive mill } \\
\text { effluent }\end{array} \\
\end{array}$ & $\begin{array}{l}\text { Dosage }: 1.0 \\
\mathrm{~g} / \mathrm{L}\end{array}$ & - & - & - & - & 95 & - & - & - & - & $\begin{array}{l}{[106} \\
]\end{array}$ \\
\hline $\begin{array}{l}\text { Paint industry } \\
\text { wastewater }\end{array}$ & $\begin{array}{ll}\text { Dosage: } & 2.0 \\
\text { g/L } & \\
\text { pH: } 9.7 & \\
\end{array}$ & 65 & - & - & - & - & - & - & 93 & - & $\begin{array}{l}{[107} \\
]\end{array}$ \\
\hline $\begin{array}{l}\text { Palm oil mill } \\
\text { effluent }\end{array}$ & $\begin{array}{l}\text { Dosage: } 0.003 \\
\text { g/L } \\
\text { pH: } 5.0 \\
\text { Temp.: } 70^{\circ} \mathrm{C}\end{array}$ & 70 & 80 & - & - & 85 & - & - & - & - & [15] \\
\hline $\begin{array}{l}\text { Papermill } \\
\text { wastewater }\end{array}$ & $\begin{array}{ll}\text { Dosage: } & 0.8 \\
\mathrm{~g} / \mathrm{L} & \\
\mathrm{pH}: 4-5 & \\
\end{array}$ & 12 & - & - & 37 & 42 & - & - & - & - & [91] \\
\hline $\begin{array}{l}\text { Personal care } \\
\text { wastewater }\end{array}$ & $\begin{array}{l}\text { Dosage: } 0.85 \\
\mathrm{~g} / \mathrm{L} \\
\text { pH: } 9.1 \\
\text { Mixing speed: } \\
267 \mathrm{rpm} \\
\end{array}$ & $\begin{array}{l}77.5 \pm \\
9.6\end{array}$ & $\begin{array}{l}78.7 \pm \\
15.6\end{array}$ & - & - & - & - & - & - & - & $\begin{array}{l}{[108} \\
]\end{array}$ \\
\hline $\begin{array}{l}\text { Petroleum } \\
\text { refinery } \\
\text { wastewater }\end{array}$ & $\begin{array}{l}\text { Dosage: } 0.623 \\
\text { g/L } \\
p H: 11.0\end{array}$ & 42.7 & - & - & 73.2 & 96.6 & - & - & 79.4 & - & [83] \\
\hline
\end{tabular}




\begin{tabular}{|c|c|c|c|c|c|c|c|c|c|c|c|}
\hline \multirow{2}{*}{$\begin{array}{l}\text { Type of } \\
\text { wastewater }\end{array}$} & \multirow{2}{*}{$\begin{array}{l}\text { Optimum } \\
\text { condition }\end{array}$} & \multicolumn{9}{|c|}{ Percentage removal $(\%)$} & \multirow[t]{2}{*}{ Ref. } \\
\hline & & COD & BOD & DO & Colour & TSS & TDS & SS & Turbidity & $\left(\mathrm{PO}_{4}\right)^{3-}$ & \\
\hline $\begin{array}{l}\text { Pesticide/agroc } \\
\text { hemical } \\
\text { wastewater }\end{array}$ & $\begin{array}{l}\text { Dosage: } 0.25 \\
\mathrm{~g} / \mathrm{L}\end{array}$ & 34.61 & 35.12 & - & - & - & - & $\begin{array}{l}52 \\
.2 \\
1 \\
\end{array}$ & - & - & $\begin{array}{l}{[109} \\
]\end{array}$ \\
\hline $\begin{array}{l}\text { Pharmaceutica } \\
\text { I wastewater }\end{array}$ & $\begin{array}{l}\text { Dosage: } 0.24 \\
\text { g/L }\end{array}$ & 32 & 33 & - & - & 77 & 40 & - & - & - & $\begin{array}{l}{[110} \\
]\end{array}$ \\
\hline $\begin{array}{l}\text { Polyacrylonitri } \\
\text { le dyeing }\end{array}$ & $\begin{array}{ll}\begin{array}{l}\text { Dosage: } \\
\mathrm{g} / \mathrm{L}\end{array} & 0.8 \\
\end{array}$ & 88 & - & - & - & - & - & - & - & - & \multirow[t]{2}{*}{$\begin{array}{l}{[101} \\
]\end{array}$} \\
\hline $\begin{array}{l}\text { Polyester } \\
\text { dyeing }\end{array}$ & $\begin{array}{ll}\begin{array}{l}\text { Dosage: } \\
\mathrm{g} / \mathrm{L}\end{array} & 0.2 \\
\end{array}$ & 73 & - & - & - & - & - & - & - & - & \\
\hline $\begin{array}{l}\text { Polymeric } \\
\text { wastewater }\end{array}$ & $\begin{array}{l}\text { Dosage: } 0.45 \\
\text { g/L } \\
\text { pH: } 9.0\end{array}$ & 78 & - & - & - & - & - & - & 75 & - & $\begin{array}{l}{[111} \\
]\end{array}$ \\
\hline $\begin{array}{l}\text { Rubber } \\
\text { processing } \\
\text { effluent }\end{array}$ & $\begin{array}{l}\text { Dosage: } \quad 1.0 \\
\mathrm{~g} / \mathrm{L} \\
\text { pH: } 5.0 \\
\text { Mixing time: } \\
60 \mathrm{~min} \\
\text { Temp.: } 70^{\circ} \mathrm{C} \\
\text { Sedimentation } \\
\text { time: } 60 \mathrm{~min}\end{array}$ & 99 & 97 & - & - & - & - & 98 & - & - & {$[48]$} \\
\hline $\begin{array}{l}\text { Sugar industry } \\
\text { wastewater }\end{array}$ & $\begin{array}{l}\text { Dosage: } \quad 0.5 \\
\text { g/L } \\
\text { pH: } 7.0 \\
\text { Temp.: } 20^{\circ} \mathrm{C}\end{array}$ & 74.5 & - & - & 87 & - & - & - & - & - & [75] \\
\hline $\begin{array}{l}\text { Synthetic } \\
\text { wastewater } \\
\text { (dye solution) }\end{array}$ & $\begin{array}{l}\text { Dosage: } \quad 0.2 \\
\text { g/L } \\
\text { pH: } 9.0 \\
\text { Temp.: } 30^{\circ} \mathrm{C} \\
\end{array}$ & 69 & - & - & 99.6 & - & - & - & - & - & {$[80]$} \\
\hline $\begin{array}{l}\text { Tannery } \\
\text { wastewater }\end{array}$ & $\begin{array}{l}\text { Dosage: } 2 \mathrm{~g} \\
\text { pH: } 7.3\end{array}$ & - & - & - & - & - & - & - & 96.6 & - & [35] \\
\hline \multirow[t]{3}{*}{$\begin{array}{l}\text { Textile } \\
\text { wastewater }\end{array}$} & $\begin{array}{l}\text { Dosage: } \quad 70 \\
\text { g/L } \\
\text { pH: 5.7-6.5 }\end{array}$ & 80.2 & 74.0 & - & 84.9 & - & - & - & - & - & $\begin{array}{l}{[100} \\
]\end{array}$ \\
\hline & $\begin{array}{ll}\text { Dosage: } & 0.6 \\
\text { g/L } & \\
\text { pH: } 6.0 & \end{array}$ & 36.8 & 50.7 & - & - & - & - & $\begin{array}{l}82 \\
.5\end{array}$ & - & - & $\begin{array}{l}{[112} \\
]\end{array}$ \\
\hline & $\begin{array}{l}\text { Dosage: } \quad 0.25 \\
\text { g/L } \\
\text { pH: } 6.0 \\
\text { Temp.: } 35^{\circ} \mathrm{C} \\
\text { Sedimentation } \\
\text { time: } 90 \text { min }\end{array}$ & 40.4 & - & - & - & - & - & - & - & - & $\begin{array}{l}{[113} \\
]\end{array}$ \\
\hline $\begin{array}{l}\text { Textile } \\
\text { wastewater }\end{array}$ & & & & & & & & & & & [94] \\
\hline $\begin{array}{c}\text { Reactive } \\
\text { Black } \\
\text { (RB) }\end{array}$ & $\begin{array}{l}\text { Dosage: } 1.0 \\
\mathrm{~g} / \mathrm{L} \\
\text { pH: } 12.0\end{array}$ & 53.32 & - & - & 96.14 & - & - & - & - & - & \\
\hline$-\begin{array}{c}\text { Cango } \\
\text { Red (CR) }\end{array}$ & $\begin{array}{l}\text { Dosage: } \\
\text { g/L } \\
\text { pH: } 11.0\end{array}$ & 51.34 & - & - & $\begin{array}{l}76.98 \\
78.65\end{array}$ & - & - & - & - & - & \\
\hline $\begin{array}{l}\text { Blue } 3 \\
\text { (DB\#) }\end{array}$ & $\begin{array}{l}\text { Dosage: } \\
\text { g/L } \\
\text { pH: } 11.0\end{array}$ & 36.09 & - & - & 39.34 & - & - & - & - & - & \\
\hline $\begin{array}{c}\text { combinati } \\
\text { on of } \\
\text { RB+CR+ } \\
\text { DB3 }\end{array}$ & $\begin{array}{l}\text { Dosage: } \\
\text { g/L } \\
\text { pH: } 12.0\end{array}$ & 39.34 & - & - & & - & - & - & - & - & \\
\hline \multirow[t]{2}{*}{$\begin{array}{l}\text { Water } \\
\text { treatment }\end{array}$} & $\begin{array}{l}\text { Dosage: } \\
10 \mathrm{~g} / 3 \mathrm{~L}\end{array}$ & 100 & 100 & $\begin{array}{l}96.3 \\
2\end{array}$ & - & $\begin{array}{l}96.5 \\
4 \\
\end{array}$ & - & - & 96.77 & 91.11 & [73] \\
\hline & $\begin{array}{l}\text { Dosage: } 0.36 \\
\mathrm{~g} / \mathrm{L}\end{array}$ & - & - & - & - & - & - & - & 96 & - & [65] \\
\hline $\begin{array}{l}\text { Winery } \\
\text { wastewater }\end{array}$ & $\begin{array}{l}\text { Dosage: } 10 \\
\text { mL of } 5 \% \mathrm{w} / \mathrm{v} \\
\text { pH: } 5.0\end{array}$ & $\begin{array}{l}\mathrm{COD}_{\text {to }} \\
\text { tal: } \\
25.0 \%\end{array}$ & - & - & - & 84.2 & - & - & 69 & - & [90] \\
\hline
\end{tabular}




\begin{tabular}{|c|c|c|c|c|c|c|c|c|c|c|c|}
\hline \multirow{2}{*}{$\begin{array}{l}\text { Type of } \\
\text { wastewater }\end{array}$} & \multirow{2}{*}{$\begin{array}{l}\text { Optimum } \\
\text { condition }\end{array}$} & \multicolumn{9}{|c|}{ Percentage removal (\%) } & \multirow[t]{2}{*}{ Ref. } \\
\hline & & COD & BOD & DO & Colour & TSS & TDS & SS & Turbidity & $\left(\mathrm{PO}_{4}\right)^{3-}$ & \\
\hline & & $\begin{array}{l}\mathrm{COD}_{\text {so }} \\
\text { luble: } \\
17.1 \%\end{array}$ & & & & & & & & & \\
\hline & $\begin{array}{l}\text { Dosage: } 20 \\
\mathrm{~mL} \text { of } 5 \% \mathrm{w} / \mathrm{v}\end{array}$ & $\begin{array}{l}\text { COD } \\
\text { tol: } \\
11.8 \% \\
\text { COD }_{\text {so }} \\
\text { luble: } \\
15.1 \%\end{array}$ & - & - & - & 60.1 & - & - & 81.6 & & \\
\hline
\end{tabular}

As shown in the table above, the performance of copperas may vary based on the type of was water and on the process condition discussed earlier in Section 3.3. As the complete coagulation/flocculation process, the floc formed. The floc from using copperas as coagulant was hard and compact as colloidal particles are stuck in the flocs stated by Rana \& Suresh [113]. Oikonomidis et al. also stated that the floc form from Fe(II) was more compact, less filamentous and smaller in size [67]. While the sludge from the coagulation process gave a comparatively sharper but still wider band at $3400 \mathrm{~cm}-1$ stated by Omprakash Sahu that might be due to the broken hydrogen bond and either free hydroxyl or a coordinated hydroxyl group is present [75].

\subsection{Integration of copperas with other chemicals in coagulation treatment.}

Some coagulants are not individually successful in removing the pollutant. It may not have the ability because it may not have the ability to neutralize all surface charges on the comparatively dense fine colloidal solids that are present in the wastewater. It needed to be added with another chemical coagulant that acts as coagulant aids. The integration of copperas includes the combination of copperas with lime, polyelectrolyte, or another chemical. The performance of combination copperas with other chemicals was shown in Table 4.

A study conducted by Satyanarayan et al. on the treatment of abattoir wastewater gave that a combination of ferrous sulfate and lime resulted in a good performance [114]. It gave good reductions of about $63.2 \%, 59.8 \%$, and $56.8 \%$ of SS, BOD, and COD, respectively, at doses $100 \mathrm{mg} / \mathrm{L}$ ferrous sulfate and $400 \mathrm{mg} / \mathrm{L}$ lime. The use of lime may remove the pollutant resulted in a higher removal [84] and may produce the alkaline solution [106]. The combination of ferrous sulfate and lime may be efficient at high $\mathrm{pH}$ values. It was efficient in iron and manganese removal and for the lime-soda softening process [63]. The addition of lime can be used to improve the $\mathrm{pH}$ and act as a coagulant/coagulant aid because of its capacity for color removal [115].

While the addition of the polyelectrolyte will strengthen the sludge formation throughout the flocculation process and result in a higher removal efficiency [114] and minimize the use of ferrous sulfate [116], the addition of polymers will promote or boost the formation of insoluble flocs as it improves settling [63]. It operates effectively at ambient $\mathrm{pH}$, especially for olive mill effluent, which was slightly acidic and thus did not drastically change the solution's pH value using polyelectrolytes [106]. It can be said that the addition of lime and polyelectrolyte avoiding the $\mathrm{pH}$ adjustment depends on the sample to be treated. 
Table 4. Application of copperas with other chemicals on the coagulation/flocculation process.

\begin{tabular}{|c|c|c|c|c|c|c|c|c|c|c|c|c|c|c|}
\hline \multirow{2}{*}{$\begin{array}{l}\text { Type } \\
\text { wastewater }\end{array}$} & \multirow[t]{2}{*}{ Coagulant } & \multirow[t]{2}{*}{ Coagulant aids } & \multirow[t]{2}{*}{ Condition } & \multicolumn{10}{|c|}{ Percentage removal $(\%)$} & \multirow{2}{*}{$\begin{array}{l}\text { Refer } \\
\text { ence }\end{array}$} \\
\hline & & & & COD & $\begin{array}{l}\text { BO } \\
\text { D }\end{array}$ & $\begin{array}{l}\text { Colou } \\
\mathbf{r}\end{array}$ & TSS & SS & TDS & $\begin{array}{l}\text { Turbidi } \\
\text { ty }\end{array}$ & $\left(\mathrm{PO}_{4}\right)^{-3}$ & $\mathrm{NH}_{3}$ & $\begin{array}{l}\text { Toxi } \\
\text { city }\end{array}$ & \\
\hline $\begin{array}{l}\text { Distillery } \\
\text { wastewater }\end{array}$ & $\begin{array}{l}20 \quad \mathrm{~g} / \mathrm{L} \\
\text { copperas }\end{array}$ & $29 \mathrm{~g} / \mathrm{L}$ lime & - & 78.5 & 80.9 & 98 & - & - & - & - & - & - & - & [116] \\
\hline $\begin{array}{l}\text { Dye and pigment } \\
\text { manufacturing } \\
\text { industrial } \\
\text { wastewater }\end{array}$ & copperas & lime & $\begin{array}{l}\text { Aeration: } 24 \mathrm{~h} \\
\mathrm{pH}: 7.0 \\
\text { Retention time: } 30 \\
\text { min }\end{array}$ & 42.1 & - & - & - & - & 40.22 & - & - & 83.07 & - & [117] \\
\hline $\begin{array}{l}\text { Municipal } \\
\text { wastewater }\end{array}$ & $\begin{array}{l}0.08 \mathrm{~g} / \mathrm{L} \\
\text { copperas }\end{array}$ & $0.02 \mathrm{~g} / \mathrm{L}$ lime & $\begin{array}{l}\text { pH:6-6.5 } \\
\text { Temp: } 30^{\circ} \mathrm{C} \\
\text { Mixing time: } 60 \mathrm{~s} \\
\text { Settling time: } 30 \\
\text { min } \\
\text { Speed: } 350 \mathrm{rpm}\end{array}$ & 60 & 50 & - & 78 & - & - & - & 73 & - & - & [84] \\
\hline $\begin{array}{l}\text { Palm oil mill } \\
\text { effluent treatment } \\
\text { (Anaerobic treated } \\
\text { sample) }\end{array}$ & $\begin{array}{l}2.0 \mathrm{~g} / \mathrm{L} \text { with } \\
\text { formulation } \\
80: 20 \quad \mathrm{CL} \\
\text { (Copperas/li } \\
\text { me) }\end{array}$ & $\begin{array}{lr}2.0 \quad \mathrm{~g} / \mathrm{L} & \text { with } \\
\text { formulation } & 80: 20 \\
\mathrm{CL} & \end{array}$ & $\begin{array}{l}\text { pH: } 7.0 \\
\text { Mixing speed: } 150 \\
\text { rpm } \\
\text { Settling time: } 30 \\
\text { min }\end{array}$ & 57 & - & 73.4 & - & - & - & 77.6 & - & - & - & [118] \\
\hline $\begin{array}{l}\text { Abattoir } \\
\text { wastewater }\end{array}$ & $\begin{array}{l}0.1 \quad \mathrm{~g} / \mathrm{L} \\
\text { copperas }\end{array}$ & $\begin{array}{l}0.1 \quad \mathrm{mg} / \mathrm{L} \\
\text { polyelectrolyte } \\
\text { (anionic) }\end{array}$ & - & 43.8 & 43.8 & - & - & 54.2 & - & - & - & - & - & [114] \\
\hline $\begin{array}{l}\text { Agrochemical/pest } \\
\text { icide wastewater }\end{array}$ & $\begin{array}{l}0.3 \mathrm{~g} / \mathrm{L} \\
\text { copperas }\end{array}$ & $\begin{array}{l}0.25 \mathrm{mg} / \mathrm{L} \\
\text { polyelectrolyte } \\
\text { (Magnafloc) }\end{array}$ & $\begin{array}{l}\text { Rapid mix: } 100 \\
\text { rpm }(1 \mathrm{~min}) \\
\text { Slow mix: } 40 \mathrm{rpm} \\
\text { (30 min) } \\
\text { Settling: } 30 \mathrm{~min}\end{array}$ & 51.13 & $\begin{array}{l}52.8 \\
0\end{array}$ & - & - & 50.23 & - & - & - & - & - & [109] \\
\hline $\begin{array}{l}\text { Refinery } \\
\text { wastewater }\end{array}$ & $\begin{array}{l}0.03 \mathrm{~g} / \mathrm{L} \\
\text { copperas }\end{array}$ & $\begin{array}{l}2.5 \quad \mathrm{mg} / \mathrm{L} \\
\text { polyacrylamide }\end{array}$ & $\begin{array}{l}\text { pH: } 6.86 \\
\text { Temp.: } 25^{\circ} \mathrm{C}\end{array}$ & - & - & - & - & - & - & 86.67 & - & - & - & [28] \\
\hline Textile wastewater & $\begin{array}{l}1.0 \mathrm{~g} / \mathrm{L} \\
\text { copperas }\end{array}$ & $\begin{array}{l}0.005 \mathrm{~g} / \mathrm{L} \text { anionic } \\
\text { polyelectrolyte } \\
(\text { Henkel } 23500)\end{array}$ & $\begin{array}{l}\text { pH: } 9.5 \\
\text { Temp.: } 20 \pm 2^{\circ} \mathrm{C} \\
\text { Rapid mix: } 100 \\
\text { rpm }(2 \text { min }) \\
\text { Slow mix: } 30 \mathrm{rpm} \\
\text { (20 min) } \\
\text { Settling: } 1 \mathrm{~h}\end{array}$ & 59 & - & - & - & - & - & - & - & - & 80 & [70] \\
\hline $\begin{array}{l}\text { Anaerobically } \\
\text { digested POME }\end{array}$ & $\begin{array}{l}25.0 \mathrm{~g} / \mathrm{L} \\
\text { copperas }\end{array}$ & $25.0 \mathrm{~g} / \mathrm{L}$ chitosan & $\begin{array}{l}\mathrm{pH}: 2.0 \\
\text { Mixing time: } 15 \\
\text { min } \\
\text { Settling time: } 1 \mathrm{~h}\end{array}$ & 62.61 & - & - & 98.7 & - & - & - & - & - & - & [95] \\
\hline
\end{tabular}




\begin{tabular}{|c|c|c|c|c|c|c|c|c|c|c|c|c|c|c|}
\hline $\begin{array}{l}\text { Textile industry } \\
\text { wastewater }\end{array}$ & $\begin{array}{l}0.6 \quad \mathrm{~g} / \mathrm{L} \\
\text { copperas }\end{array}$ & $0.4 \mathrm{~g} / \mathrm{L}$ alum & $\begin{array}{l}\text { pH: } 6.0 \\
\text { Rapid mix: } 100 \\
\text { rpm }(20 \mathrm{~s}) \\
\text { Slow mix: } 30 \mathrm{rpm} \\
\text { (30 min) } \\
\text { Settling: } 1 \mathrm{~h}\end{array}$ & 42 & 54 & 66 & - & 90 & - & - & - & - & - & [112] \\
\hline $\begin{array}{l}\text { Municipal } \\
\text { wastewater }\end{array}$ & $\begin{array}{l}0.02 \mathrm{~g} / \mathrm{L} \\
\text { copperas }\end{array}$ & $\begin{array}{l}0.06 \\
\text { sulfate }\end{array}$ & $\begin{array}{l}\text { pH:6-6.5 } \\
\text { Temp: } 30^{\circ} \mathrm{C} \\
\text { Mixing time: } 60 \mathrm{~s} \\
\text { Settling time: } 30 \\
\text { min } \\
\text { Speed: } 350 \mathrm{rpm}\end{array}$ & 61 & 50 & - & 86 & - & - & - & 76 & - & - & [18] \\
\hline $\begin{array}{l}\text { Dye and pigment } \\
\text { manufacturing } \\
\text { industrial } \\
\text { wastewater }\end{array}$ & copperas & $\mathrm{NaOH}$ & $\begin{array}{l}\text { Aeration: } 24 \mathrm{~h} \\
\text { pH: } 7.0 \\
\text { Retention time: } 30 \\
\text { min }\end{array}$ & 44.2 & - & - & - & - & 35.63 & - & - & 86.15 & - & [117] \\
\hline
\end{tabular}

Table 5. Previous finding on the integration of copperas with other chemicals in wastewater treatment.

\begin{tabular}{|c|c|c|c|c|c|c|c|c|c|}
\hline \multirow{3}{*}{$\begin{array}{l}\text { Type of } \\
\text { wastewater } \\
\text { Cotton } \\
\text { textile } \\
\text { wastewater }\end{array}$} & \multirow{2}{*}{ Coagulant } & \multirow{2}{*}{\multicolumn{2}{|c|}{ Coagulant aids }} & \multirow{2}{*}{ Condition } & \multicolumn{4}{|c|}{ Percentage removal $(\%)$} & \multirow{3}{*}{$\begin{array}{l}\text { Ref. } \\
{[120]}\end{array}$} \\
\hline & & & & & COD & BOD & Colour & SS & \\
\hline & $\begin{array}{l}1.0 \mathrm{~g} / \mathrm{L} \\
\text { copperas }\end{array}$ & $\begin{array}{l}0.8 \\
\mathrm{~g} / \mathrm{L} \\
\text { lime }\end{array}$ & $\begin{array}{l}0.008 \quad \mathrm{~g} / \mathrm{L} \\
\text { polyelectrolyte } \\
\text { (cationic) }\end{array}$ & $\begin{array}{ll}\text { pH: } & 12.0- \\
12.5 & \end{array}$ & $85-95$ & - & 70 & - & \\
\hline $\begin{array}{l}\text { Distillery } \\
\text { wastewater }\end{array}$ & $\begin{array}{l}10 \mathrm{~g} / \mathrm{L} \\
\text { copperas }\end{array}$ & $\begin{array}{l}29 \\
\mathrm{~g} / \mathrm{L} \\
\text { lime }\end{array}$ & $\begin{array}{l}0.1 \mathrm{mg} / \mathrm{L} \text { anionic } \\
\text { polyelectrolyte } \\
\text { (Percol 47) }\end{array}$ & - & 87 & 92 & 99 & - & [116] \\
\hline $\begin{array}{l}\text { Textile } \\
\text { industry } \\
\text { wastewater }\end{array}$ & $\begin{array}{l}0.6 \quad \mathrm{~g} / \mathrm{L} \\
\text { copperas }\end{array}$ & $\begin{array}{l}0.4 \\
\mathrm{~g} / \mathrm{L} \\
\text { alum }\end{array}$ & $\begin{array}{l}0.5 \quad \mathrm{mg} / \mathrm{L} \\
\text { polyelectrolyte } \\
\text { (Magnafloc } \\
1797 \text { ) }\end{array}$ & $\begin{array}{l}\text { pH: } 6.0 \\
\text { Rapid mix: } \\
100 \text { rpm (20 } \\
\text { s) } \\
\text { Slow mix: } \\
30 \text { rpm ( } 30 \\
\text { min) } \\
\text { Settling: } 1 \text { h }\end{array}$ & 45 & 56 & 72 & 92 & [112] \\
\hline
\end{tabular}


Other than that, a combination of aluminum chloride, iron (II) sulfate, and polymer has produced a new coagulating property as it connects high $\mathrm{Al}_{\mathrm{b}}$ and $\mathrm{Al}-\mathrm{OH}-\mathrm{Fe}$ bonds. The inclusion of iron limits the formation of Al-OH-Al [119]. The combination of ferrous, lime, and anionic polymer resulted in an effective removal [116]. Findings on the integration of copperas with other chemicals were tabulated in Table 5.

Copperas also have been used widely in advanced oxidation processes conducted by Villanueva-Rodríguez et al., [56] and Fenton oxidation [121] in color removal especially. In this process, hydroxyl radicals are formed in the presence of ferrous salts during the decomposition of hydrogen peroxide [122,123]. Iron species can play a role as an enhanced catalyst(as an iron catalyst) as well as a coagulant for the removal of pollutants $[55,121,122,124]$. The reaction was as follows:

$$
\mathrm{H}_{2} \mathrm{O}_{2}+\mathrm{Fe}^{2+} \rightarrow \mathrm{HO} \cdot+\mathrm{OH}^{-}+\mathrm{Fe}^{3+}
$$

Also, the addition of ferrous salt as a coagulant, the additional use of the hydrogen peroxide solution in the treatment improve process efficiency [101]. Findings on the coagulation/flocculation treatment coupled with hydrogen peroxide $\left(\mathrm{H}_{2} \mathrm{O}_{2}\right)$ were tabulated in the table below.

Table 6. Present coagulation/flocculation using copperas combined with the method of $\mathrm{H}_{2} \mathrm{O}_{2}$ treatment coagulation-flocculation- $\mathrm{H}_{2} \mathrm{O}_{2}$ oxidation).

\begin{tabular}{|c|c|c|c|c|c|c|c|c|c|c|c|c|c|}
\hline \multirow{2}{*}{$\begin{array}{l}\text { Type of } \\
\text { wastewater }\end{array}$} & \multicolumn{3}{|c|}{ Dosage } & \multirow[t]{2}{*}{ Cond. } & \multicolumn{8}{|c|}{ Percentage removal $(\%)$} & \multirow[t]{2}{*}{ Ref. } \\
\hline & Copperas & $\begin{array}{l}\text { Coagulant } \\
\text { aid (if any) }\end{array}$ & $\mathrm{H}_{2} \mathrm{O}_{2}$ & & COD & $\begin{array}{l}\text { Colou } \\
\mathbf{r}\end{array}$ & TSS & TDS & $\mathbf{T P}$ & $\begin{array}{l}\text { Phe } \\
\text { nol }\end{array}$ & $\mathrm{NH}_{3}-\mathbf{N}$ & TOC & \\
\hline $\begin{array}{l}\text { Cotton } \\
\text { dyeing }\end{array}$ & $0.2 \mathrm{~g} / \mathrm{L}$ & - & $\begin{array}{l}10 \mathrm{~cm}^{3} \\
/ \mathrm{dm}^{3}\end{array}$ & - & 88 & $>75$ & - & - & - & - & - & - & {$[101]$} \\
\hline $\begin{array}{l}\text { Polyacrylo } \\
\text { nitrile } \\
\text { dyeing }\end{array}$ & $0.8 \mathrm{~g} / \mathrm{L}$ & - & $\begin{array}{l}20 \\
\mathrm{~cm}^{3} / \mathrm{d} \\
\mathrm{m}^{3}\end{array}$ & - & 78 & 82 & - & - & - & - & - & - & \\
\hline $\begin{array}{l}\text { Polyester } \\
\text { dyeing }\end{array}$ & $0.2 \mathrm{~g} / \mathrm{L}$ & - & $\begin{array}{l}5 \\
\mathrm{~cm}^{3} / \mathrm{d} \\
\mathrm{m}^{3}\end{array}$ & - & 76 & 71 & - & - & - & - & - & - & \\
\hline $\begin{array}{l}\text { Pharmaceu } \\
\text { tical } \\
\text { wastewater }\end{array}$ & $2.45 \mathrm{~g} / \mathrm{L}$ & - & $\begin{array}{l}0.9 \\
\mathrm{~g} / \mathrm{L}\end{array}$ & - & 92 & - & - & 60 & 85 & 86 & 65 & & {$[55]$} \\
\hline $\begin{array}{l}\text { Industrial } \\
\text { wastewater } \\
\text { containing } \\
\text { nitroaroma } \\
\text { tics } \\
\end{array}$ & $10.74 \mathrm{mM}$ & - & $\begin{array}{l}132.3 \\
\mathrm{mM}\end{array}$ & $\begin{array}{l}\text { Conta } \\
\text { ct } \\
\text { time: } \\
2 \mathrm{~h}\end{array}$ & 93 & 99 & - & - & - & - & - & 80 & [121] \\
\hline $\begin{array}{l}\text { Olive mill } \\
\text { effluent }\end{array}$ & $2.5 \mathrm{~g} / \mathrm{L}$ & $\begin{array}{l}2.3 \quad \mathrm{~g} / \mathrm{L} \\
\text { polyelectrol } \\
\text { yte } \\
\text { (cationic) }\end{array}$ & $\begin{array}{l}5.0 \\
\mathrm{~g} / \mathrm{L}\end{array}$ & - & 61.4 & - & 98.3 & - & 84.9 & - & - & - & [106] \\
\hline $\begin{array}{l}\text { Anaerobica } \\
\text { lly digested } \\
\text { POME }\end{array}$ & $2.5 \mathrm{~g} / \mathrm{L}$ & $\begin{array}{l}2.5 \\
\text { chitosan }\end{array}$ & $\begin{array}{l}0.5 \\
g / L\end{array}$ & $\begin{array}{l}\mathrm{pH}: \\
7.0 \\
\text { Mixin } \\
\mathrm{g} \\
\text { time: } \\
15 \\
\text { min } \\
\text { Settlin } \\
\mathrm{g}: 1 \mathrm{~h}\end{array}$ & 89.92 & - & $\begin{array}{l}82.8 \\
2\end{array}$ & - & - & - & - & - & [95] \\
\hline
\end{tabular}

\section{Current challenges and future directions}

There are some advantages of using copperas in treating various wastewater treatment that has been produced. Iron salts have a significant sedimentation velocity, solid floc, and 
good thermal adaptability and deficiencies such as high color grade and causticity [119]. It also can control odor, thicken sludge, and is a dewatering agent for wastewater treatment [95]. Matilainen et al. and Sahu \& Chaudhari stated that ferrous sulfate is the cheapest of all salts that can be used for coagulation [29,30]. In that case, the cost in operating the coagulation/flocculation might reduce as the cost of iron salts was lower. As stated by Pandey et al., ferrous sulfate is cost-effective and has the ability for large-scale application by evaluating the prices of chemical coagulants [116].

But there were some issues regarding the use of copperas. Using iron compounds has probably not been commonly used as a primary coagulant due to color issues and oxidationreduction reactions [63]. A study stated that the use of conventional coagulants will lead to the unregulated accumulation of metal hydrolysis species [119]. Several pre-polymerized inorganic coagulants such as poly-aluminum chloride, polymeric ferric chloride, and polymeric ferric sulfate (PFS) have been developed to prevent this downside and form the ideal optimal [125]. A study stated that using copperas in water may increase the dissolved solids (salts) and require adding alkalinity [36]. In that case, the uses of iron salt require the addition of a base solution to achieve an alkalinity solution.

Future research needs to be conducted to reduce the formation of this by-product by maximizing its usage in various industries. As discussed earlier, copperas is a cost-effective chemical coagulant, and it may be used as an alternative coagulant. It is important to perform more and more future research to develop the copperas as the best coagulants or coagulant integration and coagulant aids that can produce promising results even at wider variations in $\mathrm{pH}$ and condition.

\section{Conclusions}

Overall, this review has highlighted removing a pollutant for various types of water or wastewater using copperas, a by-product from the $\mathrm{TiO}_{2}$ manufacturing process. A review of the existing literature on eliminating pollutants using the coagulation/flocculation process has been detailed above. Copperas can be utilized as a coagulant as it contains a high concentration of $\mathrm{FeO}$ and $\mathrm{SO}_{3}$ and is able to produce floc. The use of this cost-effective coagulant, copperas, or a combination with coagulant aid or coupled with hydrogen peroxide oxidation is promising in removing pollutants.

\section{Funding}

Industry Grant from Venator Asia Sdn. Bhd (vot 53396).

\section{Acknowledgments}

The authors wish to Faculty of Ocean Engineering, Technology and Informatics, Universiti Malaysia Terengganu and Venator Asia Sdn. Bhd for the industrial grant award, contribution, and supports for this project.

\section{Conflicts of Interest}

The authors declare no conflict of interest. 


\section{References}

1. Huang, P.; Deng, S.; Zhang, Z.; Wang, X.; Chen, X.; Yang, X.; Yang, L. A Sustainable Process to Utilize Ferrous Sulfate Waste from Titanium Oxide Industry by Reductive Decomposition Reaction with Pyrite. Thermochim. Acta 2015, 620, 18-27, https://doi.org/10.1016/j.tca.2015.10.004.

2. Beddow, H.; Black, S.; Read, D. Naturally Occurring Radioactive Material (NORM) from a Former Phosphoric Acid Processing Plant. J. Environ. Radioact. 2006, 86, 289-312, https://doi.org/10.1016/j.jenvrad.2005.09.006.

3. Gázquez, M. J.; Bolívar, J. P.; Garcia-Tenorio, R.; Vaca, F. A Review of the Production Cycle of Titanium Dioxide Pigment. Mater. Sci. Appl. 2014, 05, 441-458, https://doi.org/10.4236/msa.2014.57048.

4. Nayak, G.; Trivedi, M.K.; Branton, A.; Trivedi, D.; Jana, S. Solid State Characterization of the Consciousness Energy Healing Treated Magnesium. Mod. Approaches Mater. Sci. 2019, 1, 66-70.

5. Trivedi, M.K.; Jana, S. Evaluation of the Physicochemical, Thermal and Behavioural Properties of Consciousness Energy Healing Treated Iron (II) Sulphate. Bioninterface Res. Appl. Chem. 2019, 9, 42924300, https://doi.org/10.33263/BRIAC95.292300.

6. Leary, A.; Barthe, L.; Clavel, T.; Sanchez, C.; Oulmi-Castel, M.; Paillard, B.; Edmond, J. M.; Brunner, V. Pharmacokinetics of Ferrous Sulphate (Tardyferon $\left.{ }^{\circledR}\right)$ after Single Oral Dose Administration in Women with Iron Deficiency Anaemia. Drug Res. (Stuttg). 2015, 66, 51-56, https://doi.org/10.1055/s-0035-1549934.

7. Gonciarz, R. L.; Renslo, A. R. Emerging Role of Ferrous Iron in Bacterial Growth and Host-Pathogen Interaction: New Tools for Chemical (Micro)Biology and Antibacterial Therapy. Curr. Opin. Chem. Biol. 2021, 61, 170-178, https://doi.org/10.1016/j.cbpa.2021.01.015.

8. Cheng, J.; Kenaan, A.; Zhao, D.; Qi, D.; Song, J. Photo-Polymerizable Ferrous Sulfate Liposomes as Vehicles for Iron Fortification of Food. Nanomedicine Nanotechnology, Biol. Med. 2020, 30, 102286, https://doi.org/10.1016/j.nano.2020.102286.

9. Tao, Y.; Jiang, B.; Yang, X.; Ma, X.; Chen, Z.; Wang, X.; Wang, Y. Physicochemical Study of the Sustainable Preparation of Nano-Fe2O3 from Ferrous Sulfate with Coke. J. Clean. Prod. 2020, 255, 120175, https://doi.org/10.1016/j.jclepro.2020.120175.

10. Zhang, W.; Zhu, Z.; Cheng, C. Y. A Literature Review of Titanium Metallurgical Processes. Hydrometallurgy 2011, 108, 177-188, https://doi.org/10.1016/j.hydromet.2011.04.005.

11. Chernet, T. Applied Mineralogical Studies on Australian Sand Ilmenite Concentrate with Special Reference to Its Behaviour in the Sulphate Process. Miner. Eng. 1999, 12, 485-495, https://doi.org/10.1016/S08926875(99)00035-7.

12. Guskos, N.; Papadopoulos, G. J.; Likodimos, V.; Patapis, S.; Yarmis, D.; Przepiera, A.; Przepiera, K.; Majszczyk, J.; Typek, J.; Wabia, M.; Aidinis, K.; Drazek, Z. Photoacoustic, EPR and Electrical Conductivity Investigations of Three Synthetic Mineral Pigments: Hematite, Goethite and Magnetite. Mater. Res. Bull. 2002, 37, 1051-1061, https://doi.org/10.1016/S0025-5408(02)00742-0.

13. Hahn, H. H.; Hoffmann, E.; Odegaard, H. Chemical Water and Wastewater Treatment IX. Water Intell. Online 2015, 6, https://doi.org/10.2166/9781780402079.

14. Schwantes, G.; Trachet, A. Differentiation between Iron-II-Sulphate (Copperas) Staining and Natural Ochre Pigmented Lime Finishes on Lime Plaster. Int. J. Archit. Herit. 2020, 1-22, https://doi.org/10.1080/15583058.2020.1845418.

15. Bai, S. J.; Wen, S. M.; Lv, C. Preparation of Magnetic Nanoparticles from By-product of Titanium Dioxide-

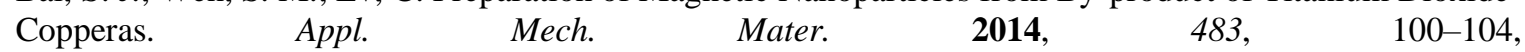
https://doi.org/10.4028/www.scientific.net/AMM.483.100.

16. Li, X.; Lei, Z.; Qu, J.; Li, Z.; Zhou, X.; Zhang, Q. Synthesizing Slow-Release Fertilizers via Mechanochemical Processing for Potentially Recycling the Waste Ferrous Sulfate from Titanium Dioxide Production. J. Environ. Manage. 2017, 186, 120-126, https://doi.org/10.1016/j.jenvman.2016.10.058.

17. Wang, W.; Shu, Y.; Xiang, H.; Xu, D.; Zhang, P.; Ren, G.; Zhong, Y.; Yang, X. Magnetic Properties of $\mathrm{Cu} 0.5 \mathrm{Mg} 0.5 \mathrm{Fe} 2 \mathrm{O} 4$ Nanoparticles Synthesized with Waste Ferrous Sulfate. Mater. Today Commun. 2020, 25, 101516, https://doi.org/10.1016/j.mtcomm.2020.101516.

18. Battah, M.; El-Ayoty, Y.; Esmael, A.; El-Ghany, S. A. Effect of Different Concentrations of Sodium Nitrate, Sodium Chloride, and Ferrous Sulphate on the Growth and Lipid Content of Chlorella Vulgaris. J. Agric. Technol. 2014, 10, 339-353.

19. Plater, M. J.; Vassiliev, K. The Detection of Glycine from the Treatment of Glyoxylic Acid with Iron(II) Sulfate and Ammonia in Water. J. Chem. Res. 2011, 35, 129-132, https://doi.org/10.3184/174751911X12964930076809.

20. Chen, F.; Li, M. Y. Preparation of Ammonium Iron Blue from Copperas and Ammonium Sulfate Wasted Liquid. Adv. Mater. Res. 2014, 898, 443-446, https://doi.org/10.4028/www.scientific.net/AMR.898.443.

21. Joseph, A.; Xavier, M. M.; Fal, J.; Żyła, G.; Sasi, S.; Radhakrishnan Nair, P.; Padmanabhan, A. S.; Mathew, S. Synthesis and Electrochemical Characterization of Electroactive IoNanofluids with High Dielectric Constants from Hydrated Ferrous Sulphate. Chem. Commun. 2019, 55, 83-86, https://doi.org/10.1039/c8cc08243j.

22. Pace, B.; Munroe, P.; Marjo, C. E.; Thomas, P.; Gong, B.; Shepherd, J.; Buss, W.; Joseph, S. The Mechanisms 
and Consequences of Inorganic Reactions during the Production of Ferrous Sulphate Enriched Bamboo Biochars. J. Anal. Appl. Pyrolysis 2018, 131, 101-112, https://doi.org/10.1016/j.jaap.2018.01.028.

23. Bulut, U.; Ozverdi, A.; Erdem, M. Leaching Behavior of Pollutants in Ferrochrome Arc Furnace Dust and Its Stabilization/Solidification Using Ferrous Sulphate and Portland Cement. J. Hazard. Mater. 2009, 162, 893898, https://doi.org/10.1016/j.jhazmat.2008.05.114.

24. Erdem, M.; Tumen, F. Chromium Removal from Aqueous Solution by the Ferrite Process. J. Hazard. Mater. 2004, 109, 71-77, https://doi.org/10.1016/j.jhazmat.2004.02.031.

25. Jančovičová, V.; Čeppan, M.; Havlínová, B.; Reháková, M.; Jakubíková, Z. Interactions in Iron Gall Inks. Chem. Pap. 2007, 61, 391-397, https://doi.org/10.2478/s11696-007-0053-0.

26. Husain, A.; Javed, I.; Khan, N.A. Characterization and Treatment of Electroplating Industry Wastewater Using Fenton's Reagent. J. Chem. Pharm. Res. 2014, 6, 622-627.

27. Barrera-Díaz, C.; Martínez-Barrera, G.; Gencel, O.; Bernal-Martínez, L. A.; Brostow, W. Processed Wastewater Sludge for Improvement of Mechanical Properties of Concretes. J. Hazard. Mater. 2011, 192, 108-115, https://doi.org/10.1016/j.jhazmat.2011.04.103.

28. Hassan, A.A.; Naeem, H.T.; Hadi, R.T. A Comparative Study of Chemical Material Additives On Polyacrylamide to Treatment of Waste Water in Refineries. IOP Conf. Ser. Mater. Sci. Eng. 2019, 518, 062003, https://doi.org/10.1088/1757-899X/518/6/062003.

29. Matilainen, A.; Lindqvist, N.; Tuhkanen, T. Comparison of the Efficiency of Aluminium and Ferric Sulphate in the Removal of Natural Organic Matter during Drinking Water Treatment Process. Environ. Technol. 2005, 26, 867-876, https://doi.org/10.1080/09593332608618502.

30. Sahu, O.; Chaudhari, P. Review on Chemical Treatment of Industrial Waste Water. J. Appl. Sci. Environ. Manag. 2013, 17, 241-257, https://doi.org/10.4314/jasem.v17i2.8.

31. Radin Mohamed, R. M. S.; Ibrahim Kutty, N. M. A.; Mohd Kassim, A. H. Efficiency of Using Commercial and Natural Coagulants in Treating Car Wash Wastewater Treatment. Aust. J. Basic Appl. Sci. 2014, 8, 227234.

32. Yu, Y. T.; Liu, B. G.; Chen, G.; Peng, J. H.; Srinivasakannan, C. Optimization of Hydrous Ferrous Sulfate Dehydration by Microwave Heating Using Response Surface Methodology. J. Microw. Power Electromagn. Energy 2012, 46, 206-214, https://doi.org/10.1080/08327823.2012.11689837.

33. Gázquez, M. J.; Bolívar, J. P.; García-Tenorio, R.; Vaca, F. Physicochemical Characterization of Raw Materials and Co-Products from the Titanium Dioxide Industry. J. Hazard. Mater. 2009, 166, 1429-1440, https://doi.org/10.1016/j.jhazmat.2008.12.067.

34. Aziz, H.A.; Wan Kamar, W.I.S. Initial Investigation on Using Copperas By-Product to Remove Colour from Domestic Wastewater by Coagulation and Flocculation. Adv. Environ. Biol. 2014, 8, 78-82.

35. Prakash, N. B.; Sockan, V.; Jayakaran, P. Waste Water Treatment by Coagulation and Flocculation. Certif. Int. J. Eng. Sci. Innov. Technol. 2014, 9001, 2319-5967.

36. Prabhakaran, G.; Manikandan, M.; Boopathi, M. Treatment of Textile Effluents by Using Natural Coagulants. Mater. Today Proc. 2019, 33, 3000-3004, https://doi.org/10.1016/j.matpr.2020.03.029.

37. Hamzah, S.; Ali, N.; Mohammad, A. W.; Ariffin, M. M.; Ali, A. Design of Chitosan/PSf Self-Assembly Membrane to Mitigate Fouling and Enhance Performance in Trypsin Separation. J. Chem. Technol. Biotechnol. 2012, 87, 1157-1166, https://doi.org/10.1002/jctb.3740.

38. Ali, A.; Dzul Rashidi, N.F.; Hamzah, S.; Wan Abdul Rahman, W.R.; Azaman, F. Preparation and Characterization of Polyethersulfone/Natural Clay Nanocomposite Membrane. J. Adv. Res. Mater. Sci. 2019, $54,10-17$.

39. Othman, N.; Heng, L. C.; Noah, N. F. M.; Yi, O. Z.; Jusoh, N.; Nasruddin, N. A.; Ali, N.; Hamzah, S. Removal of Phenol from Wastewater by Supported Liquid Membrane Process. J. Teknol. 2015, 74, 117-121, https://doi.org/10.11113/jt.v74.4709.

40. Rumaizah, C. Z.; Fazureen, A.; Mohd Hasmizam, R.; Asmadi, A.; Mohd Al Amin, M. N. Properties and Filtration Performance of Porous Clay Membrane Produced Using Sawdust as Pore Forming Agent. Key Eng. Mater. 2019, 821, 337-342, https://doi.org/10.4028/www.scientific.net/KEM.821.337.

41. Mouratib, R.; Achiou, B.; Krati, M. El; Younssi, S. A.; Tahiri, S. Low-Cost Ceramic Membrane Made from Alumina- and Silica-Rich Water Treatment Sludge and Its Application to Wastewater Filtration. J. Eur. Ceram. Soc. 2020, 40, 5942-5950, https://doi.org/10.1016/j.jeurceramsoc.2020.07.050.

42. Muniz, G. L.; Borges, A. C.; Silva, T. C. F. da. Performance of Natural Coagulants Obtained from AgroIndustrial Wastes in Dairy Wastewater Treatment Using Dissolved Air Flotation. J. Water Process Eng. 2020, 37, 101453, https://doi.org/10.1016/j.jwpe.2020.101453.

43. Wu, H.; Huang, Y.; Liu, B.; Han, G.; Su, S.; Wang, W.; Yang, S.; Xue, Y.; Li, S. An Efficient Separation for Metal-Ions from Wastewater by Ion Precipitate Flotation: Probing Formation and Growth Evolution of MetalReagent Flocs. Chemosphere 2021, 263, 128363, https://doi.org/10.1016/j.chemosphere.2020.128363.

44. Hamzah, S.; Razali, N. A.; Yatim, N. I.; Alias, M.; Ali, A.; Zaini, N. S.; Abuhabib, A. A. M. Characterisation and Performance of Thermally Treated Rice Husk as Efficient Adsorbent for Phosphate Removal. J. Water Supply Res. Technol. - AQUA 2018, 67, 766-778, https://doi.org/10.2166/aqua.2018.087.

45. Hamzah, S.; Ilyana Yatim, N.; Alias, M.; Ali, A.; Rasit, N.; Abuhabib, A. Extraction of Hydroxyapatite from Fish Scales and Its Integration with Rice Husk for Ammonia Removal in Aquaculture Wastewater. Indones. 
J. Chem. 2019, 19, 1019-1030, https://doi.org/10.22146/ijc.40907.

46. Marinah, M. A., Yatim, N.I. and Hamzah, S. Synthesis and Characterization of Hydroxyapatite From Bulk Seashells and Its Potential Usage As lead Ion Adsorbent. Malay.J. of Analy. Sc. 2017, 21, 571-584, https://doi.org/10.17576/mjas-2017-2103-07

47. Hossain, M. S.; Omar, F.; Asis, A. J.; Bachmann, R. T.; Islam Sarker, M. Z.; Ab Kadir, M. O. Effective Treatment of Palm Oil Mill Effluent Using FeSO $4.7 \mathrm{H} 2 \mathrm{O}$ Waste from Titanium Oxide Industry: Coagulation Adsorption Isotherm and Kinetics Studies. J. Clean. Prod. 2019, 219, 86-98, https://doi.org/10.1016/j.jclepro.2019.02.069.

48. Ngteni, R.; Hossain, M. S.; Kadir, M. O. A.; Asis, A. J.; Tajudin, Z. Kinetics and Isotherm Modeling for the Treatment of Rubber Processing Euent Using Iron (II) Sulphate Waste as a Coagulant. Water 2020, 12, 118, https://doi.org/10.3390/W12061747.

49. Dotto, J.; Fagundes-Klen, M. R.; Veit, M. T.; Palácio, S. M.; Bergamasco, R. Performance of Different Coagulants in the Coagulation/Flocculation Process of Textile Wastewater. J. Clean. Prod. 2019, 208, 656665, https://doi.org/10.1016/j.jclepro.2018.10.112.

50. Xu, Q.; Huang, Q. S.; Luo, T. Y.; Wu, R. L.; Wei, W.; Ni, B. J. Coagulation Removal and Photocatalytic Degradation of Microplastics in Urban Waters. Chem. Eng. J. 2021, 416, 129123, https://doi.org/10.1016/j.cej.2021.129123.

51. Zhao, X.; Wei, H.; Zhao, H.; Wang, Y.; Tang, N. Electrode Materials for Capacitive Deionization: A Review. J. Electroanal. Chem. 2020, 873, 114416, https://doi.org/10.1016/j.jelechem.2020.114416.

52. Sayed, E. T.; Al Radi, M.; Ahmad, A.; Abdelkareem, M. A.; Alawadhi, H.; Atieh, M. A.; Olabi, A. G. Faradic Capacitive Deionization (FCDI) for Desalination and Ion Removal from Wastewater. Chemosphere 2021, 275, 130001, https://doi.org/10.1016/j.chemosphere.2021.130001.

53. Ochando-Pulido, J. M.; Vellido-Pérez, J. A.; González-Hernández, R.; Martínez-Férez, A. Optimization and Modeling of Two-Phase Olive-Oil Washing Wastewater Integral Treatment and Phenolic Compounds Recovery by Novel Weak-Base Ion Exchange Resins. Sep. Purif. Technol. 2020, 249, 117084, https://doi.org/10.1016/j.seppur.2020.117084.

54. Dixit, F.; Dutta, R.; Barbeau, B.; Berube, P.; Mohseni, M. PFAS Removal by Ion Exchange Resins: A Review. Chemosphere 2021, 272, 129777, https://doi.org/10.1016/j.chemosphere.2021.129777.

55. Shetty, R.; Verma, S. Fenton's Reagent for the Treatment of Pharmaceutical Industry Wastewater. Int. J. Sci. Res. 2013, 4, 3093-3096.

56. Villanueva-Rodríguez, M.; Hernández-Ramírez, A.; Peralta-Hernández, J. M.; Bandala, E. R.; Quiroz-Alfaro, M. A. Enhancing the Electrochemical Oxidation of Acid-Yellow 36 Azo Dye Using Boron-Doped Diamond Electrodes by Addition of Ferrous Ion. J. Hazard. Mater. 2009, 167, 1226-1230, https://doi.org/10.1016/j.jhazmat.2008.12.137.

57. Ma, D.; Yi, H.; Lai, C.; Liu, X.; Huo, X.; An, Z.; Li, L.; Fu, Y.; Li, B.; Zhang, M.; Qin, L.; Liu, S.; Yang, L. Critical Review of Advanced Oxidation Processes in Organic Wastewater Treatment. Chemosphere 2021, 275, 130104, https://doi.org/10.1016/j.chemosphere.2021.130104.

58. Ouyang, W.; Chen, T.; Shi, Y.; Tong, L.; Chen, Y.; Wang, W.; Yang, J.; Xue, J. Physico-Chemical Processes. Water Environ. Res. 2019, 91, 1350-1377, https://doi.org/10.1002/wer.1231.

59. Pavón-Silva, T.; Pacheco-Salazar, V.; Carlos Sánchez-Meza, J.; Roa-Morales, G.; Colín-Cruz, A. Physicochemical and Biological Combined Treatment Applied to a Food Industry Wastewater for Reuse. $J$. Environ. Sci. Heal. - Part A Toxic/Hazardous Subst. Environ. Eng. 2009, 44, 108-115, https://doi.org/10.1080/10934520802515467.

60. AlMubaddal, F.; AlRumaihi, K.; Ajbar, A. Performance Optimization of Coagulation/Flocculation in the Treatment of Wastewater from a Polyvinyl Chloride Plant. J. Hazard. Mater. 2009, 161, 431-438, https://doi.org/10.1016/j.jhazmat.2008.03.121.

61. Szyguła, A.; Guibal, E.; Palacín, M. A.; Ruiz, M.; Sastre, A. M. Removal of an Anionic Dye (Acid Blue 92) by Coagulation-Flocculation Using Chitosan. J. Environ. Manage. 2009, 90, 2979-2986, https://doi.org/10.1016/j.jenvman.2009.04.002.

62. Alexander, J. T.; Hai, F. I.; Al-aboud, T. M. Chemical Coagulation-Based Processes for Trace Organic Contaminant Removal: Current State and Future Potential. J. Environ. Manage. 2012, 111, 195-207, https://doi.org/10.1016/j.jenvman.2012.07.023.

63. Iwuozor, K. O. Prospects and Challenges of Using Coagulation-Flocculation Method in the Treatment of Effluents. Adv. J. Chem. A 2019, 2, 105-127, https://doi.org/10.29088/sami/ajca.2019.2.105127.

64. Teh, C. Y.; Wu, T. Y.; Juan, J. C. Potential Use of Rice Starch in Coagulation-Flocculation Process of AgroIndustrial Wastewater: Treatment Performance and Flocs Characterization. Ecol. Eng. 2014, 71, 509-519, https://doi.org/10.1016/j.ecoleng.2014.07.005.

65. Yakubu, M. L.; Daura, H. A. Comparative Study of Alum and Four Other Selected Coagulants in the Removal of Raw Water Turbididty. Technol. Sci. Africana J. 2011, 6, 125-129.

66. Banu, J. R.; Do, K. U.; Yeom, I. T. Effect of Ferrous Sulphate on Nitrification during Simultaneous Phosphorus Removal from Domestic Wastewater Using a Laboratory Scale Anoxic/Oxic Reactor. World J. Microbiol. Biotechnol. 2008, 24, 2981-2986, https://doi.org/10.1007/s11274-008-9841-0.

67. Oikonomidis, I.; Burrows, L. J.; Carliell-Marquet, C. M. Mode of Action of Ferric and Ferrous Iron Salts in 
Activated Sludge. J. Chem. Technol. Biotechnol. 2010, 85, 1067-1076, https://doi.org/10.1002/jctb.2399.

68. Wang, Y.; Tng, K. H.; Wu, H.; Leslie, G.; Waite, T. D. Removal of Phosphorus from Wastewaters Using Ferrous Salts - A Pilot Scale Membrane Bioreactor Study. Water Res. 2014, 57, 140-150, https://doi.org/10.1016/j.watres.2014.03.029.

69. Valve, M.; Rantanen, P.; Kallio, J. Enhancing Biological Phosphorus Removal from Municipal Wastewater with Partial Simultaneous Precipitation. Water Sci. Technol. 2002, 46, 249-255, https://doi.org/10.2166/wst.2002.0598.

70. Selcuk, H. Decolorization and Detoxification of Textile Wastewater by Ozonation and Coagulation Processes. Dye. Pigment. 2005, 64, 217-222, https://doi.org/10.1016/j.dyepig.2004.03.020.

71. Khajababu, A.; Gupta, S. K. Optimum Dose of Coagulant for Natural Surface Waters. Asian J. Microbiol. Biotechnol. Environ. Sci. 2014, 16, 957-964.

72. Bratby, J. Coagulation and Flocculation in Water and Wastewater Treatment; 2016. https://doi.org/10.2166/9781780407500.

73. Mbaeze, M.; Agbazue, V.; Orjioke, N. Comparative Assessment of Performance of Aluminium Sulphate (Alum) and Ferrous Sulphate as Coagulants in Water Treatment. Mod. Chem. Appl. 2017, 05, https://doi.org/10.4172/2329-6798.1000233.

74. Keeley, J.; Smith, A. D.; Judd, S. J.; Jarvis, P. Reuse of Recovered Coagulants in Water Treatment: An Investigation on the Effect Coagulant Purity Has on Treatment Performance. Sep. Purif. Technol. 2014, 131, 69-78, https://doi.org/10.1016/j.seppur.2014.04.033.

75. Sahu, O. Effectiveness of Ferrous Material on Chemical and Thermal Oxidation on Sugar Industries Wastewater with Sludge Analysis: Batch Mode. Sustain. Water Resour. Manag. 2018, 4, 415-424, https://doi.org/10.1007/s40899-017-0116-5.

76. Bieda, B. Life Cycle Inventory Processes of the ArcelorMittal Poland (AMP) S.A. in Kraków, Poland-Basic Oxygen Furnace Steel Production. Int. J. Life Cycle Assess. 2012, 17, 463-470, https://doi.org/10.1007/s11367-011-0370-y.

77. Nandy, T.; Shastry, S.; Pathe, P. P.; Kaul, S. N. Pre-Treatment of Currency Printing Ink Wastewater through Coagulation-Flocculation Process. Water. Air. Soil Pollut. 2003, 148, 15-30, https://doi.org/10.1023/A:1025454003863.

78. Zouboulis, A. I.; Tzoupanos, N. D. Polyaluminium Silicate Chloride-A Systematic Study for the Preparation and Application of an Efficient Coagulant for Water or Wastewater Treatment. J. Hazard. Mater. 2009, 162, 1379-1389, https://doi.org/10.1016/j.jhazmat.2008.06.019.

79. Chaudhari, P. K.; Majumdar, B.; Choudhary, R.; Yadav, D. K.; Chand, S. Treatment of Paper and Pulp Mill Effluent by Coagulation. Environ. Technol. 2010, 31, 357-363, https://doi.org/10.1080/09593330903486665.

80. Asilian, H.; Fard, S. M.; Rezaei, A.; Mortazavi, S. B.; Khavanin, A. The Removal of Color and COD from Wastewater Containing Water Base Color by Coagulation Process. Int. J. Environ. Sci. Technol. 2006, 3, 153-157, https://doi.org/10.1007/BF03325919.

81. Hamidi, A. A.; Alias, S.; Assari, F.; Adlan, M. N. The Use of Alum, Ferric Chloride and Ferrous Sulphate as Coagulants in Removing Suspended Solids, Colour and COD from Semi-Aerobic Landfill Leachate at Controlled PH. Waste Manag. Res. 2007, 25, 556-565, https://doi.org/10.1177/0734242X07079876.

82. Parmar, K. A.; Prajapati, S.; Patel, R.; Dabhi, Y. Effective Use of Ferrous Sulfate and Alum as a Coagulant in Treatment of Dairy Industry Wastewater. J. Eng. Appl. Sci. 2011, 6, 42-45.

83. Lynn, T. Y.; Mohd Omar, F.; Abdul Aziz, H.; Nik Ab Rahman, N. N. Ferrous Sulphate From Titanium Dioxide Industry in Organic and Inorganic Contaminant Removal from Petroleum Refinery Wastewater. Recent Adv. Energy, Environ. Financ. Sci. 2016, 135-140.

84. Ismail, I. M.; Fawzy, A. S.; Abdel-Monem, N. M.; Mahmoud, M. H.; El-Halwany, M. A. Combined Coagulation Flocculation Pre Treatment Unit for Municipal Wastewater. J. Adv. Res. 2012, 3, 331-336, https://doi.org/10.1016/j.jare.2011.10.004.

85. Kushwaha, J. P.; Chandra Srivastava, V.; Mall, I. D. Treatment of Dairy Wastewater by Inorganic Coagulants: Parametric and Disposal Studies. Water Res. 2010, 44, 5867-5874, https://doi.org/10.1016/j.watres.2010.07.001.

86. Duan, J.; Gregory, J. Coagulation by Hydrolysing Metal Salts. Adv. Colloid Interface Sci. 2003, 100-102, 475-502, https://doi.org/10.1016/S0001-8686(02)00067-2.

87. Al-Gheethi, A. A.; Mohamed, R. M. S. R.; Wurochekke, A. A.; Nurulainee, N. R.; Mas Rahayu, J.; Amir Hashim, M. K. Efficiency of Moringa Oleifera Seeds for Treatment of Laundry Wastewater. MATEC Web Conf. 2017, 103, 1-8, https://doi.org/10.1051/matecconf/201710306001.

88. Baskan, M. B.; Pala, A. Determination of Arsenic Removal Efficiency by Ferric Ions Using Response Surface Methodology. J. Hazard. Mater. 2009, 166, 796-801, https://doi.org/10.1016/j.jhazmat.2008.11.131.

89. Adesoye, A. M.; Olayinka, K.; Olukomaiya, O. O.; Iwuchukwu, P. O. The Removal of Phosphates from Laundry Wastewater Using Alum and Ferrous Sulphate as Coagulants. Int. J. Innov. Sci. Res. 2014, 8, 256260.

90. Braz, R.; Pirra, A.; Lucas, M. S.; Peres, J. A. Combination of Long Term Aerated Storage and Chemical Coagulation/Flocculation to Winery Wastewater Treatment. Desalination 2010, 263, 226-232, https://doi.org/10.1016/j.desal.2010.06.063. 
91. Irfan, M.; Butt, T.; Imtiaz, N.; Abbas, N.; Khan, R. A.; Shafique, A. The Removal of COD, TSS and Colour of Black Liquor by Coagulation-Flocculation Process at Optimized PH, Settling and Dosing Rate. Arab. J. Chem. 2013, 10, S2307-S2318, https://doi.org/10.1016/j.arabjc.2013.08.007.

92. Sinha, S.; Yoon, Y.; Amy, G.; Yoon, J. Determining the Effectiveness of Conventional and Alternative Coagulants through Effective Characterization Schemes. Chemosphere 2004, 57, 1115-1122, https://doi.org/10.1016/j.chemosphere.2004.08.012.

93. Suman, A.; Ahmad, T.; Ahmad, K. Dairy Wastewater Treatment Using Water Treatment Sludge as Coagulant: A Novel Treatment Approach. Environ. Dev. Sustain. 2018, 20, 1615-1625, https://doi.org/10.1007/s10668-017-9956-2.

94. Verma, A. K.; Bhunia, P.; Dash, R. R. Supremacy of Magnesium Chloride for Decolourisation of Textile Wastewater: A Comparative Study on the Use of Different Coagulants. Int. J. Environ. Sci. Dev. 2012, 3, 118-123, https://doi.org/10.7763/ijesd.2012.v3.200.

95. Parthasarathy, S.; Gomes, R. L.; Manickam, S. Process Intensification of Anaerobically Digested Palm Oil Mill Effluent (AAD-POME) Treatment Using Combined Chitosan Coagulation, Hydrogen Peroxide (H2O2) and Fenton's Oxidation. Clean Technol. Environ. Policy 2016, 18, 219-230, https://doi.org/10.1007/s10098015-1009-7.

96. Ahmad, A. L.; Ibrahim, N.; Ismail, S.; Bhatia, S. Coagulation-Sedimentation-Extraction Pretreatment Methods for The Removal of Suspended Solids and Residual Oil From Palm Oil Mill Effluent (Pome). IIUM Eng. J. 2002, 3, 25-33, https://doi.org/10.31436/iiumej.v3i1.351.

97. Ukiwe, L.; Iwu, I. C.; Okere M, C. The Role of Inorganic Metal Salts in Wastewater Clarification. J. Adv. Chem. 2016, 12, 318-322, https://doi.org/10.24297/jac.v12i8.2841.

98. Verma, A. K.; Dash, R. R.; Bhunia, P. A Review on Chemical Coagulation/Flocculation Technologies for Removal of Colour from Textile Wastewaters. J. Environ. Manage. 2012, 93, 154-168, https://doi.org/10.1016/j.jenvman.2011.09.012.

99. Bouranene, S.; Sedira, N.; Fievet, P.; Attia, N. Treatment of Paint Wastewater by Coagulation Process. Filtr. Sep. 2015, 52, 42-45, https://doi.org/10.1016/S0015-1882(15)30184-1.

100.Patel, H.; Vashi, R. T. Treatment of Textile Wastewater by Adsorption and Coagulation. E-Journal Chem. 2010, 7, 1468-1476, https://doi.org/10.1155/2010/987620.

101.Perkowski, J.; Kos, L. Treatment of Textile Dyeing Wastewater by Hydrogen Peroxide and Ferrous Ions. Fibres Text. East. Eur. 2002, 10, 78-81.

102.Ang, W. L.; Mohammad, A. W.; Benamor, A.; Hilal, N. Chitosan as Natural Coagulant in Hybrid Coagulation-Nanofiltration Membrane Process for Water Treatment. J. Environ. Chem. Eng. 2016, 4, 48574862, https://doi.org/10.1016/j.jece.2016.03.029.

103.Loloei, M.; Nekonam, G.; Alidadi, H.; Kor, Y. Study of the Coagulation Process in Wastewater Treatment of Dairy Industries. Int. J. Environ. Health Eng. 2014, 3, 12, https://doi.org/10.4103/2277-9183.132684.

104.Nassef, E. Removal of Phosphates from Industrial Waste Water by Chemical Precipitation . Eng. Sience Technol. An Int. J. 2012, 2, 409-413.

105.Samadi, M. T.; Saghi, M. H.; Rahmani, A.; Hasanvand, J.; Rahimi, S.; Syboney, M. S. Hamadan Landfill Leachate Treatment by Coagulation-Flocculation Process. Iran. J. Environ. Heal. Sci. Eng. 2010, 7, $253-258$.

106.Ginos, A.; Manios, T.; Mantzavinos, D. Treatment of Olive Mill Effluents by Coagulation-FlocculationHydrogen Peroxide Oxidation and Effect on Phytotoxicity. J. Hazard. Mater. 2006, B133, 135-142, https://doi.org/10.1016/j.jhazmat.2005.10.024.

107.Dovletoglou, O.; Philippopoulos, C.; Grigoropoulou, H. Coagulation for Treatment of Paint Industry Wastewater. J. Environ. Sci. Heal. - Part A Toxic/Hazardous Subst. Environ. Eng. 2002, 37, 1361-1377, https://doi.org/10.1081/ESE-120005992.

108.El-Gohary, F.; Tawfik, A.; Mahmoud, U. Comparative Study between Chemical Coagulation/Precipitation (C/P) versus Coagulation/Dissolved Air Flotation (C/DAF) for Pre-Treatment of Personal Care Products (PCPs) Wastewater. Desalination 2010, 252, 106-112, https://doi.org/10.1016/j.desal.2009.10.016.

109. Misra, R.; Satyanarayan, S.; Potle, N. Treatment of Agrochemical / Pesticide Wastewater by Coagulation / Flocculation Process. Int. J. Chem. Phys. Sci. 2013, 2, 39-51.

110. Saleem, M. Pharmaceutical Wastewater Treatment: A Physicochemical Study. J. Res. 2007, 18, $125-134$.

111. Al-Malack, M. H.; Abuzaid, N. S.; El-Mubarak, A. H. Coagulation of Polymeric Wastewater Discharged by a Chemical Factory. Water Res. 1999, 33, 521-529, https://doi.org/10.1016/S0043-1354(98)00219-X.

112.Pathe, P. P.; Biswas, A. K.; Rao, N. N.; Kaul, S. N. Physico-Chemical Treatment of Wastewater from Clusters of Small Scale Cotton Textile Units. Environ. Technol. 2005, 26, 313-328, https://doi.org/10.1080/09593332608618562.

113.Rana, S.; Suresh, S. Comparison of Different Coagulants for Reduction of COD from Textile Industry Wastewater. Mater. Today Proc. 2017, 4, 567-574, https://doi.org/10.1016/j.matpr.2017.01.058.

114.Satyanarayan, S.; Ramakant; Vanerkar, A. P. Conventional Approach for Abattoir Wastewater Treatment. Environ. Technol. 2005, 26, 441-448, https://doi.org/10.1080/09593332608618554.

115.Gao, B. Y.; Yue, Q. Y.; Wang, Y.; Zhou, W. Z. Color Removal from Dye-Containing Wastewater by $\begin{array}{llllll}\text { Magnesium } \quad \text { Chloride. } & \text { J. } & \text { Environ. } & \text { Manage. } & \text { 2007, } & \text { 82, }\end{array}$ https://doi.org/10.1016/j.jenvman.2005.12.019. 
116.Pandey, R. A.; Malhotra, S.; Tankhiwale, A.; Pande, S.; Pathe, P. P.; Kaul, S. N. Treatment of Biologically Treated Distillery Effluent - A Case Study. Int. J. Environ. Stud. 2003, 60, 263-275, https://doi.org/10.1080/00207230290024270.

117.Lodhi, R. S.; Lal, N. Dyes and Pigments Manufacturing Industrial Waste Water Treatment Methodology. Int. Res. J. Eng. Technol. 2008, 9001, 121-131.

118.Mohamad, N. A., Hamzah, S., Harun, M. H. C., Ali, A., Rasit, N., Awang, M., ... \& Saad, R. Integration of copperas and calcium hydroxide as a chemical coagulant and coagulant aid for efficient treatment of palm oil mill effluent. Chemosphere 2021, 281, 130873, https://doi.org/10.1016/j.chemosphere.2021.130873.

119.Pan, L. T.; Wang, W. L.; Yu, B.; Shu, Y. B. The Preparation and Characterization of a New High Polymeric Flocculant-Polymeric Aluminum Ferric Sulfate Chloride. Adv. Mater. Res. 2012, 356-360, 445-450, https://doi.org/10.4028/www.scientific.net/AMR.356-360.445.

120.Georgiou, D.; Aivazidis, A.; Hatiras, J.; Gimouhopoulos, K. Treatment of Cotton Textile Wastewater Using Lime and Ferrous Sulfate. Water Res. 2003, 37, 2248-2250, https://doi.org/10.1016/S0043-1354(02)004815.

121.Vithalkar, S. H.; Rao, S. N.; Shivastva, S.; Sathe, A. M. Kinetic Study of Oxidation of Nitrophenol Present in Waste Water Using Ferrous Sulphate. Mater. Today Proc. 2019, 15, 620-625, https://doi.org/10.1016/j.matpr.2019.04.129.

122. Murray, C. A.; Parsons, S. A. Removal of NOM from Drinking Water: Fenton's and Photo-Fenton's Processes. Chemosphere 2004, 54, 1017-1023, https://doi.org/10.1016/j.chemosphere.2003.08.040.

123.Sanz, J.; Lombraña, J. I.; De Luis, A. M.; Ortueta, M.; Varona, F. Microwave and Fenton's Reagent Oxidation of Wastewater. Environ. Chem. Lett. 2003, 1, 45-50, https://doi.org/10.1007/s10311-002-0007-2.

124.Goslan, E. H.; Gurses, F.; Banks, J.; Parsons, S. A. An Investigation into Reservoir NOM Reduction by UV Photolysis and Advanced Oxidation Processes. Chemosphere 2006, 65, 1113-1119, https://doi.org/10.1016/j.chemosphere.2006.04.041.

125.Zouboulis, A. I.; Moussas, P. A.; Vasilakou, F. Polyferric Sulphate: Preparation, Characterisation and Application in Coagulation Experiments. J. Hazard. Mater. 2008, 155, 459-468, https://doi.org/10.1016/j.jhazmat.2007.11.108. 